ARTICLE

https://doi.org/10.1038/s41467-020-16428-w

\title{
Accumulation of ambient phosphate into the periplasm of marine bacteria is proton motive force dependent
}

\author{
Nina A. Kamennaya ${ }^{1,2,5}$, Kalotina Geraki (D) ${ }^{3}$, David J. Scanlan (1D ${ }^{2}$ \& Mikhail V. Zubkov (1) 1,4凶
}

\begin{abstract}
Bacteria acquire phosphate $\left(P_{i}\right)$ by maintaining a periplasmic concentration below environmental levels. We recently described an extracellular $P_{\mathrm{i}}$ buffer which appears to counteract the gradient required for $P_{i}$ diffusion. Here, we demonstrate that various treatments to outer membrane $(O M)$ constituents do not affect the buffered $P_{i}$ because bacteria accumulate $P_{i}$ in the periplasm, from which it can be removed hypo-osmotically. The periplasmic $\mathrm{P}_{\mathrm{i}}$ can be gradually imported into the cytoplasm by ATP-powered transport, however, the proton motive force (PMF) is not required to keep $\mathrm{P}_{\mathrm{i}}$ in the periplasm. In contrast, the accumulation of $P_{i}$ into the periplasm across the OM is PMF-dependent and can be enhanced by light energy. Because the conventional mechanism of $\mathrm{P}_{\mathrm{i}}$-specific transport cannot explain $\mathrm{P}_{\mathrm{i}}$ accumulation in the periplasm we propose that periplasmic $P_{i}$ anions pair with chemiosmotic cations of the PMF and millions of accumulated $\mathrm{P}_{\mathrm{i}}$ pairs could influence the periplasmic osmolarity of marine bacteria.
\end{abstract}

\footnotetext{
${ }^{1}$ National Oceanography Centre, Southampton SO14 3ZH, UK. ${ }^{2}$ School of Life Sciences, University of Warwick, Gibbet Hill, Coventry CV4 7AL, UK. 
hosphorus $(\mathrm{P})$ is a macronutrient universally required by all organisms including bacteria. Bacteria have a number of ways to acquire P. Scavenging $\mathrm{P}$ from organic molecules and reducing growth dependence on $\mathrm{P}$ by substituting $\mathrm{P}$ with sulfur in their membranes ${ }^{1-6}$ are both beneficial for bacteria living in phosphate $\left(\mathrm{P}_{\mathrm{i}}\right)$-depleted marine environments. However, there is compelling evidence that bacteria prefer $\mathrm{P}_{\mathrm{i}}$ to organic $\mathrm{P}$ molecules ${ }^{7-9}$. Marine bacteria, which typically have two membranes (and therefore stain Gram negative), acquire $P_{i}$ using a diffusion gradient between the environment and the periplasm ${ }^{10,11}$. In their cells, the periplasm is separated from the environment by the outer membrane (OM), whose permeability to small, hydrophilic solutes is controlled mainly by hydrated channels-porins (Fig. la $\dagger$ ). Porins select solutes on the basis of their size, shape and charge ${ }^{12,13}$. When nutrients such as $P_{i}$ become depleted, cells increase the number of porins to facilitate nutrient diffusion ${ }^{14}$.

There are the three known bacterial transport systems to import $\mathrm{P}_{\mathrm{i}}$ from the periplasm into the cytoplasm: a low affinityhigh velocity phosphate inorganic transport (Pit) system, a low affinity-high velocity Na-dependent phosphate transport (Npt) system and a high affinity-low velocity phosphate-specific transport (Pst) system ${ }^{15-17}$. Bacteria living in $\mathrm{P}_{\mathrm{i}}$-depleted waters use only the Pst system ${ }^{18,19}$. The PstCAB transporter is ATPpowered and receives $P_{i}$ from a carrier protein, a PstS subunit, when the latter docks at its periplasmic side (Fig. 1a $\dagger$ ). Although the $\mathrm{P}_{\mathrm{i}}$ concentration of $\sim 10^{-7} \mathrm{~mol} \mathrm{l}^{-1}$ required for efficient import of $\mathrm{P}_{\mathrm{i}}$ by $\mathrm{PstSCAB}^{20}$ is relatively high, it should not restrict $\mathrm{P}_{\mathrm{i}}$ diffusion into the periplasm, because the periplasmic volume of even a relatively large bacterial cell, e.g., Synechococcus

a



Fig. 1 Phosphate $\left(\mathbf{P}_{\mathbf{i}}\right)$ acquisition by marine bacteria. a In a model cell labelled with ${ }^{\star} P_{i}$ the ${ }^{\star} P_{i}$-tracer can be (i) extracellular, i.e., adsorbed onto the cell surface; (ii) accumulated in the periplasm; (iii) bound to the PstS subunit in the periplasm; (iv) in a labile form in the cytoplasm, e.g., soluble $P_{i}$, nucleotides, sugar phosphates, small molecules of RNA; and ( $v$ ) in a non-labile form of assimilated P, e.g., DNA, ribosomal RNA, polyphosphates, phospholipids. ar Current understanding-parallel processes of passive adsorption of $P_{i}$ to the bacterial cell surface composed of polymers of the outer membrane lipopolysaccharide (LPS) and overlaid (in some bacteria) by the proteinaceous surface layer (S-layer) and $\mathrm{P}_{\mathrm{i}}$ diffusion across the outer membrane through porins into the periplasm. Diffusion is coupled directly to $P_{i}$ transport across the cytoplasmic membrane by ABC-type transporters (PstCAB) using the periplasmic $P_{i}$-binding protein (PstS). a: The proposed model-mass transfer of $P_{i}$ anions across the outer membrane through porins, their buffering by cations of the membrane potential in the periplasm and import of $P_{i}$ from the buffered stock through the cytoplasmic membrane by PstCAB using $P_{i}$-PstS. Isotonic or slightly hypertonic osmotic pressure is maintained in the periplasm by the buffered $P_{i}$ salt. $\mathbf{b}-\mathbf{e}$ Removal of different phosphorus pools by washing or fixation of a model ${ }^{\star} P_{i}-$ labelled Synechococcus cell. b Treatment with surfactants, hydrolytic enzymes and amended ASW removes the extracellular $P_{i}$ adsorbed to cell surface constituents. c $A$ short wash with hypotonic solution, e.g., deionized water (DW), dissolves the extracellularly adsorbed $\mathrm{P}_{\mathrm{i}}$ and, by causing osmotic shock, releases the periplasmic contents of a cell, i.e., the accumulated and PstS-bound $\mathrm{P}_{\mathrm{i}}$. d Fixation of cells with paraformaldehyde (PFA) compromises the outer and inner membranes, releasing labile periplasmic and intracellular $\mathrm{P}_{\mathrm{i}}$, but crosslinks cellular proteins, immobilizing the primary phosphorus-containing macromolecules including DNA, rRNA and $\mathrm{P}_{\mathrm{i}}$-carrying PstS subunits. e Fixation of cells with trichloroacetic acid (TCA) disrupts membranes and precipitates cellular macromolecules (proteins, nucleic acids, polyphosphates and polysaccharides), thereby releasing labile $\mathrm{P}_{\mathrm{i}}$ but immobilizing most of the assimilated $\mathrm{P}_{\mathrm{i}}$. 
cyanobacteria (Supplementary Table 1) with an estimated periplasmic depth ${ }^{21}$ of $10^{-8} \mathrm{~m}$, is only about $2 \times 10^{-17} \mathrm{l}$. In such a tiny volume, the presence of only a few free $\mathrm{P}_{\mathrm{i}}$ molecules would exceed the threshold $10^{-7} \mathrm{moll}^{-1} \mathrm{P}_{\mathrm{i}}$ concentration (Fig. 1a $\dagger$ ).

Bacteria maximize the diffusive flux of nutrients through the OM by maintaining a steep nutrient concentration gradient between the environment and periplasm ${ }^{10,11}$. Consequently, to allow efficient diffusion of $\mathrm{P}_{\mathrm{i}}$ into the periplasm in $\mathrm{P}_{\mathrm{i}}$-depleted $\left(10^{-9}-10^{-8} \mathrm{~mol} \mathrm{l}^{-1}\right)$ oceanic surface waters ${ }^{7,22}$, the periplasmic $P_{i}$ concentration should hypothetically be $<10^{-9} \mathrm{moll}^{-1}$. This means that there should be no free $P_{i}$ molecules in the periplasm, i.e., every $P_{i}$ molecule entering the periplasm should be instantly bound by a PstS subunit requiring an affinity $>100$ times above the known PstS affinity limit. However, the PstS affinity requirement does not seem to limit the growth of ubiquitous SAR11 alphaproteobacteria and Prochlorococcus cyanobacteriathe two bacterial populations comprising $\leq 3 / 4$ of oceanic surface bacterioplankton in the $\mathrm{P}_{\mathrm{i}}$-depleted North Atlantic subtropical gyre $^{7}$. Furthermore, the ecological success of these bacteria is probably related to the high rates of $P_{i}$ uptake measured in the gyre ${ }^{7,22}$. Surprisingly, measured rates of $P_{i}$ acquisition by Prochlorococcus and SAR11 are lower in tropical surface waters where bacterial growth and $\mathrm{P}_{\mathrm{i}}$ concentrations are higher ${ }^{22}$. The counter-intuitive reduction in the $\mathrm{P}_{\mathrm{i}}$ acquisition rate by faster growing bacteria was attributed to the presence of an intermediate buffer, in which both SAR11 and Prochlorococcus cells store $P_{i}$ : the fuller the $P_{i}$ buffer is, e.g., in $P_{i}$-replete tropical surface waters, the fewer $P_{i}$ molecules a cell acquires slower from seawater to top the buffer up 22 . As every $\mathrm{P}_{\mathrm{i}}$ molecule acquired, or more precisely accumulated, by a cell first enters the buffer before being imported for assimilation, bacterial $P_{i}$ uptake into the buffer and $\mathrm{P}_{\mathrm{i}}$ import from the buffer can be decoupled. Although Prochlorococcus and SAR11 bacteria possess genes related to synthesis of polyphosphates ${ }^{23}$, their cells are perhaps too small to store $\mathrm{P}_{\mathrm{i}}$ as polyphosphates intracellularly and they somehow accumulate $P_{i}$ extracellularly.

Our aim here is to explain how marine bacteria accumulate $P_{i}$ extracellularly. We demonstrate that $\mathrm{P}_{\mathrm{i}}$ accumulation rates by oceanic SAR11, Prochlorococcus and Synechococcus cells are extremely variable in the $\mathrm{P}_{\mathrm{i}}$-depleted North Atlantic. Lower rates can be stimulated by light energy but their maximal rates are insensitive to light and approach the theoretical upper limit of diffusion. To relate the accumulated $P_{i}$ with cellular $P_{i}$ requirements, the P contents of flow-sorted cells of oceanic Prochlorococcus and SAR11 were determined by microbeam synchrotron X-ray fluorescence ( $\mu$-SXRF) using flow-sorted cultured Synechococcus cells for calibration. Using pulse-chase experiments with ${ }^{33} \mathrm{P}_{\mathrm{i}}$ and ${ }^{32} \mathrm{P}_{\mathrm{i}}\left({ }^{*} \mathrm{P}_{\mathrm{i}}\right)$ radiotracers, we showed that cultured Synechococcus cells accumulate $\mathrm{P}_{\mathrm{i}}$ in a similar way to SAR11 and Prochlorococcus cells ${ }^{22}$. This justified the use of Synechococcus isolates for more intrusive tests (e.g., of retention of accumulated $\mathrm{P}_{\mathrm{i}}$ ), to curtail artefacts resulting from the low tolerance of oceanic SAR11 and Prochlorococcus bacteria to harsh experimental manipulations. Moreover, by working with artificial seawater (ASW), we expanded the experimental range of $P_{i}$ concentrations below those encountered in natural $\mathrm{P}_{\mathrm{i}}$-depleted seawater. To examine how the extracellular $P_{i}$ is retained, we developed a living cellular model system with the extracellular ${ }^{*} \mathrm{P}_{\mathrm{i}}$-labelled buffer (Fig. 1a) and treated them with hydrolytic enzymes, surfactants, inhibitors, amended ASW and hypotonic solutions to locate whether the $P_{i}$ buffer is on the cell surface (Fig. 1b), e.g., retained by a charged S-layer, as was recently proposed for archaea ${ }^{24}$, or in the periplasm (Fig. 1c). We used specific metabolic inhibitors ${ }^{25-28}$ to determine whether the proton motive force (PMF) is driving extracellular $\mathrm{P}_{\mathrm{i}}$ accumulation and retention.
Based on our field and laboratory experiments, we conclude that the PMF is essential for $P_{i}$ accumulation (but not retention) in the periplasm of marine bacteria. As the PstS-driven import cannot explain $\mathrm{P}_{\mathrm{i}}$ accumulation in the periplasm, we propose a mechanism of periplasmic ionic pairing of inwardly diffusing $P_{i}$ anions with chemiosmotic cations of the membrane potential (Fig. 1a $\ddagger$ ), which could conserve cellular energy and control periplasmic turgor.

\section{Results}

Bacterial clearance rates of $P_{i} . P_{i}$ clearance rates (the volume of water cleared of $P_{i}$ by a cell per unit of time, while the cell accumulates the cleared $\mathrm{P}_{\mathrm{i}}$ ) of oceanic SAR11, Prochlorococcus and Synechococcus cells vary by orders of magnitude in the patchily $\mathrm{P}_{\mathrm{i}}$-depleted North Atlantic (Supplementary Figs. 1 and 2a, and Supplementary Table 2). Living in such a patchy environment warrants the use of an extracellular buffer, where $P_{i}$ is temporarily stored ${ }^{22}$. Mostly the measured rates are lower in waters adjacent to the subtropical gyre with higher in situ $P_{i}$ concentrations, whereas the rates are higher in the central gyre waters with lower $P_{i}$ concentrations $\left(18-28^{\circ} \mathrm{N}\right.$, Supplementary Fig. 2a and Supplementary Table 2). In the central gyre waters, maximal $P_{i}$ clearance rates of SAR11, Prochlorococcus and Synechococcus cells (Fig. 2 a) are only $30 \times, 40 \times$ and $25 \times$, respectively, below the theoretical maximal rate of nutrient acquisition by diffusion ${ }^{10,11}$. Apparently, a Synechococcus cell can accumulate $P_{i}$ faster than either a Prochlorococcus or a SAR11 cell. To understand why the abundance of Synechococcus in the central gyre waters is three orders of magnitude lower than the abundance of Prochlorococcus and SAR11, we need to take into account cell sizes and cellular $P$ requirements of these bacteria.

Once their maximal $\mathrm{P}_{\mathrm{i}}$ clearance rates are normalized to cellular biovolumes (Supplementary Table 1 and Fig. 2a) then a Prochlorococcus, a Synechococcus or a SAR11 cell can theoretically clear all dissolved $\mathrm{P}_{\mathrm{i}}$ from seawater $\leq 2.5 \times 10^{4}, 2.6 \times 10^{4}$ or $1.2 \times$ $10^{5}$ times its cellular volume $\mathrm{min}^{-1}$, respectively. In agreement with the surface area-to-volume concept ${ }^{29}$, these biovolumespecific clearance rates show that a SAR11 cell is noticeably (4-5X) more effective in uptake of $P_{i}$ than either a Prochlorococcus cell or a Synechococcus cell probably owing to the $2 \times$ higher surface area-to-volume ratio of a small, curved-rod shape SAR11 cell compared with the cocci cyanobacteria (Supplementary Fig. 3 and Supplementary Table 1).

To account for the cellular Ps requirements of oceanic bacterial cells, we determined their cellular $\mathrm{P}$ content. The cellular $\mathrm{P}$ content of a Synechococcus cell $\left(1.93 \times 10^{7} \mathrm{P}\right.$ atoms cell $\left.{ }^{-1}\right)$ and hence their $\mathrm{P}$ demand is $5-7 \times$ higher than the $\mathrm{P}$ content of a Prochlorococcus and a SAR11 cell $\left(4.14\right.$ and $2.68 \times 10^{6} \mathrm{P}$ atoms cell $^{-1}$, respectively, Fig. $2 \mathrm{~b}$ and Supplementary Table 3). This implies that Synechococcus growth in $\mathrm{P}_{\mathrm{i}}$-depleted waters is constrained by its high $\mathrm{P}$ demand rather than by its ability to acquire $\mathrm{P}_{\mathrm{i}}$. It is also notable that a larger Synechococcus and a smaller Prochlorococcus have similar biovolume-specific $P_{i}$ clearance rates, despite the $1.2 \times$ higher cell surface-to-volume ratio of the latter (Supplementary Table 1). As porin-restricted diffusion constrains the $\mathrm{P}_{\mathrm{i}}$ clearance rate, the OM of Synechococcus ought to be more permeable to $\mathrm{P}_{\mathrm{i}}$, e.g., to have more $\mathrm{P}_{\mathrm{i}}$ specific porins per $\mu \mathrm{m}^{2}$ of the OM surface.

The above comparisons show that despite its high $\mathrm{P}$ demand, a Synechococcus cell is a good model system for studying the process of $P_{i}$ acquisition by oceanic bacteria. In our laboratory studies, we focused on the oligotrophic Synechococcus sp. strain WH8102 but also made comparisons with the mesotrophic Synechococcus strains WH8109 and WH7803 ${ }^{30}$. The 40-90x lower $\mathrm{P}_{\mathrm{i}}$ clearance rate of larger cells of cultured Synechococcus 


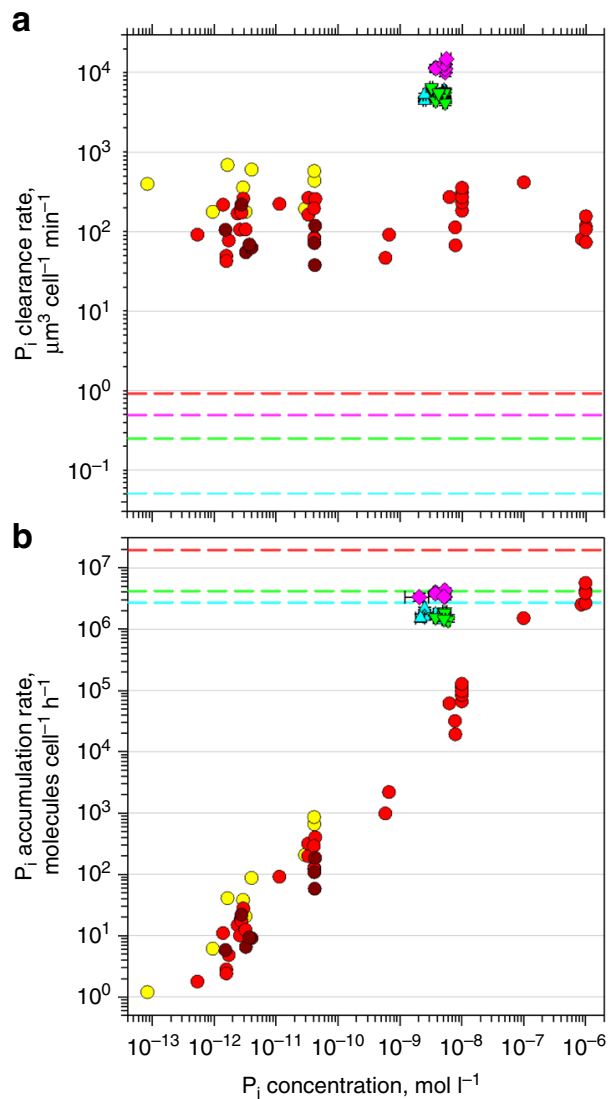

Fig. $2 \mathbf{P}_{\mathbf{i}}$ acquisition rates of oceanic and cultured cells. a Comparison of cellular $P_{i}$ clearance rates of oceanic SAR11 (light blue triangles, $n=14$ ), Prochlorococcus (green triangles, $n=11$ ) and Synechococcus (pink diamonds, $n=7$ ) at ambient $P_{i}$ concentrations with rates of cultured Synechococcus strains WH7803 (yellow circles, $n=10$ ), WH8102 (red circles, $n=35$ ) and WH8109 (brown circles, $n=8$ ) across a wide range of $P_{i}$ concentrations. b Comparison of maximal cellular $P_{i}$ accumulation rates of the same bacteria (SAR11 $n=12$, Prochlorococcus $n=7$, Synechococcu $n=7$, WH7803 $n=10$, WH8102 $n=35$ and WH8109 $n=8)$. Dashed lines indicate corresponding (a) cellular volumes $\left(\mu \mathrm{m}^{3}\right.$ cell $^{-1}$ ) and (b) cellular phosphorus content (P atoms cell ${ }^{-1}$ ) of oceanic SAR11 (light blue), Prochlorococcus (green), Synechococcus (pink) and cultured Synechococcus sp. WH8102 (orange). Horizontal grey lines indicate major ticks of the logarithmic $\mathrm{Y}$-axis to assist comparing values. Symbols present individual measurements for cultured Synechococcus cells and mean values of four sorting replicates for oceanic bacteria; error bars indicate corresponding $\mathrm{SD}$. The full range of rates of oceanic bacteria is shown in Supplementary Fig. 2. Source data are provided as a Source Data file.

compared with oceanic bacterioplankton suggests that Synechococcus cells grown at a $P_{i}$ concentration $>10^{-5} \mathrm{moll}^{-1}$ have fewer porins ${ }^{12,13}$ than oceanic bacteria even when the $P_{i}$ concentration is downshifted (Fig. 2a). Such porin-restricted diffusion explains why a cultured Synechococcus cell cleared $\mathrm{P}_{\mathrm{i}}$ from about the same volume of water, while the $P_{i}$ concentration ranged over more than seven orders of magnitude. The $\mathrm{P}_{\mathrm{i}}$ clearance rate of cultured Synechococcus cells remained relatively constant between the three strains down to the low end of the tested $P_{i}$ concentrations (Fig. 2a), such that within a few hours these cells removed virtually all ${ }^{33} \mathrm{P}_{\mathrm{i}}$ or ${ }^{32} \mathrm{P}_{\mathrm{i}}$ tracers from the medium (Supplementary Table 4). Using carrier-free ${ }^{32} \mathrm{P}_{\mathrm{i}}$ tracer, we determined that the final $\mathrm{P}_{\mathrm{i}}$ concentration in the surrounding seawater was depleted by Synechococcus to $10^{-15} \mathrm{moll}^{-1}$ (the instrument detection limit), or six orders of magnitude below oceanic $\mathrm{P}_{\mathrm{i}}$ levels (Supplementary Table 2).

Fast growth-decoupled accumulation of $\mathbf{P}_{\mathbf{i}}$. The rate of $\mathrm{P}_{\mathrm{i}}$ accumulation (the amount of $\mathrm{P}_{\mathrm{i}}$ molecules accumulated by a cell per unit of time) by cultured Synechococcus cells was proportional to the $\mathrm{P}_{\mathrm{i}}$ concentration over a range of concentrations from $10^{-13}$ to $10^{-6} \mathrm{moll}^{-1}$ (Fig. 2b), much wider than the range of $10^{-9}-10^{-8} \mathrm{moll}^{-1}$ offered by the $\mathrm{P}_{\mathrm{i}}$-depleted North Atlantic (Supplementary Table 2). At $\mathrm{P}_{\mathrm{i}}$ concentrations similar to $\mathrm{P}_{\mathrm{i}}$-depleted oceanic waters, cultured cells accumulated $\mathrm{P}_{\mathrm{i}}$ orders of magnitude slower than oceanic SAR11, Prochlorococcus and Synechococcus cells (Fig. $2 \mathrm{~b}$ and Supplementary Fig. 2b). At $10^{-6}$ mol $\mathrm{P}_{\mathrm{i}} 1^{-1}$, a cultured Synechococcus cell can, however, double its cellular P content within merely $3 \mathrm{~h}$ (Fig. $2 \mathrm{~b}$ and Supplementary Table 3), while they divide once every 1-2 days. Similarly, when related to their cellular $\mathrm{P}$ content, oceanic Prochlorococcus and SAR11 cells obtained sufficient $P_{i}$ for cell division in merely 1-2 $\mathrm{h}$, whereas in such oligotrophic waters Prochlorococcus divide only once every 3.5 days $^{31}$ and SAR11 once every 2-3 days (calculated based on their cellular leucine uptake rates ${ }^{32}$ ). This decoupling of $\mathrm{P}_{\mathrm{i}}$ accumulation and growth rates in Synechococcus, Prochlorococcus and SAR11 cells suggests that, apart from being a reserve for steady growth, the accumulated $\mathrm{P}_{\mathrm{i}}$ could have an additional, important cellular function.

Synechococcus cells accumulate $\mathbf{P}_{\mathbf{i}}$ extracellularly. To assess whether cultured Synechococcus cells accumulate $\mathrm{P}_{\mathrm{i}}$ in the extracellular buffer, the accumulation of the ${ }^{33} \mathrm{P}_{\mathrm{i}}$-pulse and ${ }^{32} \mathrm{P}_{\mathrm{i}^{-}}$ chase was determined in live WH8102 cells (total $\mathrm{P}_{\mathrm{i}}$, Fig. 1a) and in their cellular macromolecules (biomass fixed with paraformaldehyde (PFA) that immobilizes DNA and RNA-the two principal $\mathrm{P}_{\mathrm{i}}$-containing macromolecules-as well as some periplasmic constituents, including PstS subunits) (Fig. 1d). After addition of the $10^{-6} \mathrm{~mol} \mathrm{l}^{-132} \mathrm{P}_{\mathrm{i}}$-chase, accumulation of the ${ }^{33} \mathrm{P}_{\mathrm{i}}$ pulse into cellular macromolecules should be halted, because any of the $4.5-7 \times 10^{-9} \mathrm{moll}^{-1}{ }^{33} \mathrm{P}_{\mathrm{i}}$-pulse that remains in the seawater would be diluted with the chase $>100 \times$. However, similar to that observed in oceanic bacteria ${ }^{22}$, the pulsed ${ }^{33} \mathrm{P}_{\mathrm{i}}$ continued to be assimilated into cell macromolecules at an unchanged rate, which started slowing down only after $5 \mathrm{~h}$ (Fig. 3a, c). Usually in pulse-chase experiments, incorporation of a pulsed molecule (e.g., amino acid or nucleoside) into bacterial macromolecules halts abruptly upon dilution with the chase, because the intermediate cellular labile pool of the pulsed molecule is small, e.g., $5 \%$ of the tracer incorporated into macromolecules ${ }^{33}$. In the case of $\mathrm{P}_{\mathrm{i}}$, that labile pool was $10 \times-20 \times$ larger than the amount assimilated into cellular macromolecules (Fig. $3 \mathrm{~b}, \mathrm{~d}$ at the $3 \mathrm{~h}$ time point).

We then used the difference in ${ }^{*} \mathrm{P}_{\mathrm{i}}$ label between the total $\mathrm{P}_{\mathrm{i}}$ in live cells and macromolecule-bound $\mathrm{P}_{\mathrm{i}}$ to estimate the amount of labile $\mathrm{P}_{\mathrm{i}}$ in three Synechococcus strains. This showed the total ${ }^{*} \mathrm{P}_{\mathrm{i}}$ content of tested live cells (Fig. $4 \mathrm{a}$ ) to be consistently several times higher than the ${ }^{*} \mathrm{P}_{\mathrm{i}}$ content of cellular macromolecules (fixed with either PFA or trichloroacetic acid (TCA), Fig. 1d,e and Supplementary Fig. 4). Furthermore, in the ${ }^{*} \mathrm{P}_{\mathrm{i}}$ pre-labelled cells, which were washed and suspended in ASW with no ${ }^{*} \mathrm{P}_{\mathrm{i}}$ (see Methods), the ${ }^{*} \mathrm{P}_{\mathrm{i}}$ content in macromolecules increased with time and approached the total ${ }^{*} \mathrm{P}_{\mathrm{i}}$ that remained stable (Fig. $4 \mathrm{~b}$ ). With no ${ }^{*} \mathrm{P}_{\mathrm{i}}$ in the medium, the additional ${ }^{*} \mathrm{P}_{\mathrm{i}}$ gained by the macromolecules can only be sourced from ${ }^{*} \mathrm{P}_{\mathrm{i}}$ accumulated in the intermediate buffer. These data also show that the accumulated ${ }^{*} \mathrm{P}_{\mathrm{i}}$ is semi-labile and can be imported into the cytoplasm to synthesize nucleic acids.

To confirm the extracellular (i.e., not in the cytoplasm) location of the labile $\mathrm{P}_{\mathrm{i}}$, we washed cells for 1-2 min with deionized water 
a

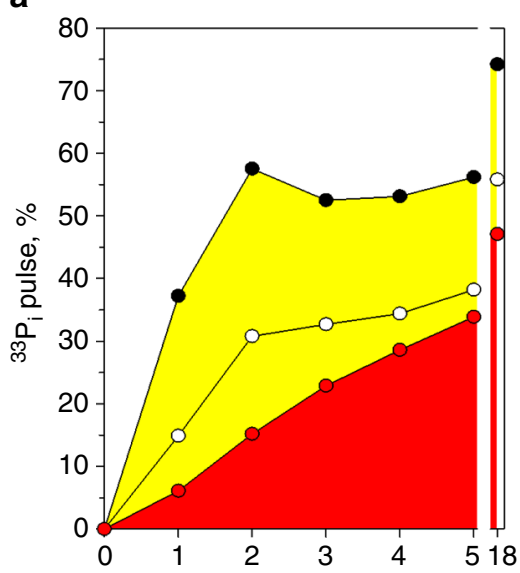

b

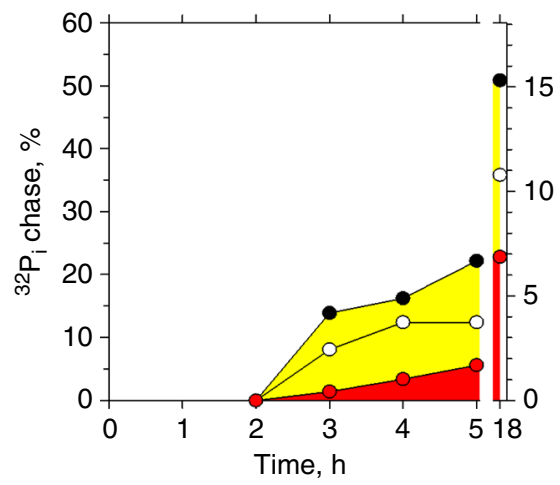

C

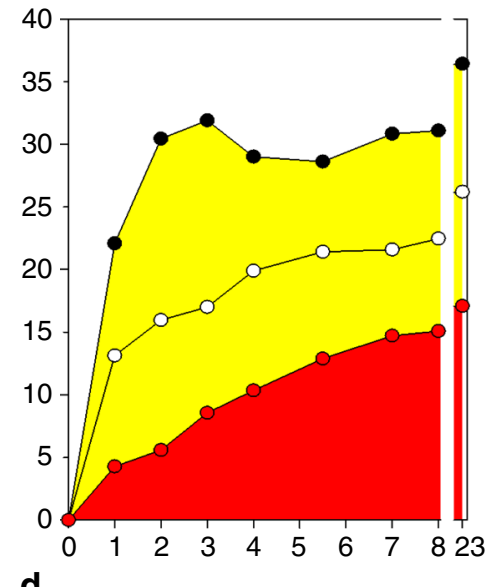

d

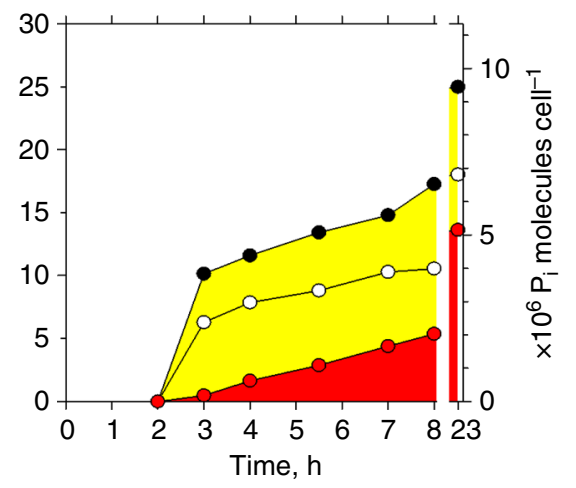

Fig. $3 \mathbf{P}_{\mathbf{i}}$ accumulation by Synechococcus sp. WH8102. Left $(\mathbf{a}, \mathbf{b})$ and right $(\mathbf{c}, \mathbf{d})$ panels show the results of two representative pulse-chase experiments with cells at exponential and early stationary growth phases, respectively. $\mathbf{a}$, $\mathbf{c}$ Accumulation dynamics of $10^{-8}$ mol $\mathrm{I}^{-133} \mathrm{P}_{\mathrm{i}}$-pulse added at $0 \mathrm{~h}$ in live cells washed with artificial seawater - the total $P_{i}$ (black circles), live cells washed with deionized water - the cytoplasmic $P_{i}$ (white circles) and in the PFA-fixed cellular biomass - the macromolecule-bound $\mathrm{P}_{\mathrm{i}}$ (red circles), as a percentage of added tracer. $\mathbf{b}$, $\mathbf{d}$ Accumulation dynamics of the $10^{-6}$ mol I-132 $\mathrm{P}_{\mathrm{i}}$-chase added at $2 \mathrm{~h}$ as the total $\mathrm{P}_{\mathrm{i}}$, the cytoplasmic $\mathrm{P}_{\mathrm{i}}$ and the macromolecule-bound $\mathrm{P}_{\mathrm{i}}$. The additional right $\mathrm{Y}$-axis $(\mathbf{b}, \mathbf{d})$ shows cellular rates of ${ }^{32} \mathrm{P}_{\mathrm{i}}$-chase accumulation. To assist comparison of the labile and non-labile $P_{i}$, the areas below lines are coloured yellow for the labile $P_{i}$ and red for non-labile $P_{i}$. Symbols are connected with lines to indicate the slopes of the ${ }^{33} \mathrm{P}_{\mathrm{i}}$ and ${ }^{32} \mathrm{P}_{\mathrm{i}}$ tracer accumulation. The $\mathrm{X}$-axis is broken to add an additional, final time point. Circles present mean values of technical duplicates or individual measurements. Source data are provided as a Source Data file.

(DW). Washing live cells with DW effectively strips $\mathrm{P}_{\mathrm{i}}$ and other ions adsorbed to the OM components. In addition, such brief hypo-osmotic shock also releases the content of the periplasm without disrupting the plasma membrane. Western blotting analysis confirmed the presence of the periplasmic $\mathrm{P}_{\mathrm{i}}$-binding subunits PstS in the DW-washed fraction but detected no Rubisco, arguably the most abundant soluble protein in the cyanobacterial cytoplasm (Fig. 5a, b). In fact, even a $30 \mathrm{~min}$ incubation of Synechococcus in DW did not lyse the cells (Fig. 5c). As a substantial fraction of the accumulated ${ }^{*} \mathrm{P}_{\mathrm{i}}$ was removed with a brief rinse of live Synechococcus with DW (Fig. 3), we therefore conclude that their cells accumulate $P_{i}$ outside the plasma membrane, i.e., on the surface of the $\mathrm{OM}$ or in the periplasm (Fig. 1a $\dagger$ ).

Periplasmic location and retention of the $P_{i}$ in Synechococcus. To identify the exact location of the accumulated $\mathrm{P}_{\mathrm{i}}$ and to assess whether $\mathrm{P}_{\mathrm{i}}$ was associated with specific cell surface ligands, we examined the response of live ${ }^{*} \mathrm{P}_{\mathrm{i}}$ pre-labelled Synechococcus cells to a variety of treatments, which are inapplicable to delicate oceanic bacteria (Fig. 1b, c and Supplementary Tables 5 and 6). Treatments with surfactants released no ${ }^{*} \mathrm{P}_{\mathrm{i}}$ (Fig. 6), suggesting that it is not associated directly with OM lipids. High concentrations of a broad-spectrum protease Proteinase K, which was shown to efficiently digest extracellular proteins in bacteria ${ }^{34,35}$, did not release the accumulated ${ }^{*} \mathrm{P}_{\mathrm{i}}$, implying no direct involvement of extracellular proteins (including the S-layer proteins of WH8102 ${ }^{36}$ ) in $\mathrm{P}_{\mathrm{i}}$ accumulation (Fig. 6). Release of the accumulated $\mathrm{P}_{\mathrm{i}}$ did not happen after destabilization of the spatial conformation of lipopolysaccharides (LPS) by depletion of $\mathrm{Ca}^{2+}$ and $\mathrm{Mg}^{2+}$ di-cations ${ }^{37}$ (ASW-P $\mathrm{P}_{\mathrm{i}} \mathrm{Ca}$ and $\mathrm{NaCl}+$ EDTA) or by lysozyme treatment ${ }^{38}$ (Fig. 6), suggesting no direct involvement of LPS in $\mathrm{P}_{\mathrm{i}}$ accumulation. Retention of $\mathrm{P}_{\mathrm{i}}$ by phosphorylation of extracellular macromolecules was ruled out, because alkaline phosphatase had no effect on the accumulated $\mathrm{P}_{\mathrm{i}}$ (Fig. 6). Incubations with either acidic ( $\mathrm{pH}$ 6) or alkaline ( $\mathrm{pH} 10)$ ASW failed to remove the accumulated $\mathrm{P}_{\mathrm{i}}$ (Fig. 6), demonstrating an insignificant effect of (de)protonation on the stability of the accumulated $\mathrm{P}_{\mathrm{i}}$.

To assess the role of PMF in retention of the accumulated $\mathrm{P}_{\mathrm{i}}$, we treated ${ }^{*} \mathrm{P}_{\mathrm{i}}$ pre-labelled Synechococcus cells with the inhibitor carbonyl cyanide m-chloro-phenyl-hydrazone (CCCP) (Supplementary Table 7). Dissipation of the PMF had a minor effect on the already accumulated $\mathrm{P}_{\mathrm{i}}$ : the amount of released $\mathrm{P}_{\mathrm{i}}$ was comparable to the amount of $\mathrm{P}_{\mathrm{i}}$ lost by washing live cells with ASW- $P_{i}$ (Supplementary Fig. 4). In contrast to the above treatments, accumulated $\mathrm{P}_{\mathrm{i}}$ was easily removed by short (1-2 $\mathrm{min})$ rinses of live cells with a range of hypotonic solutions 

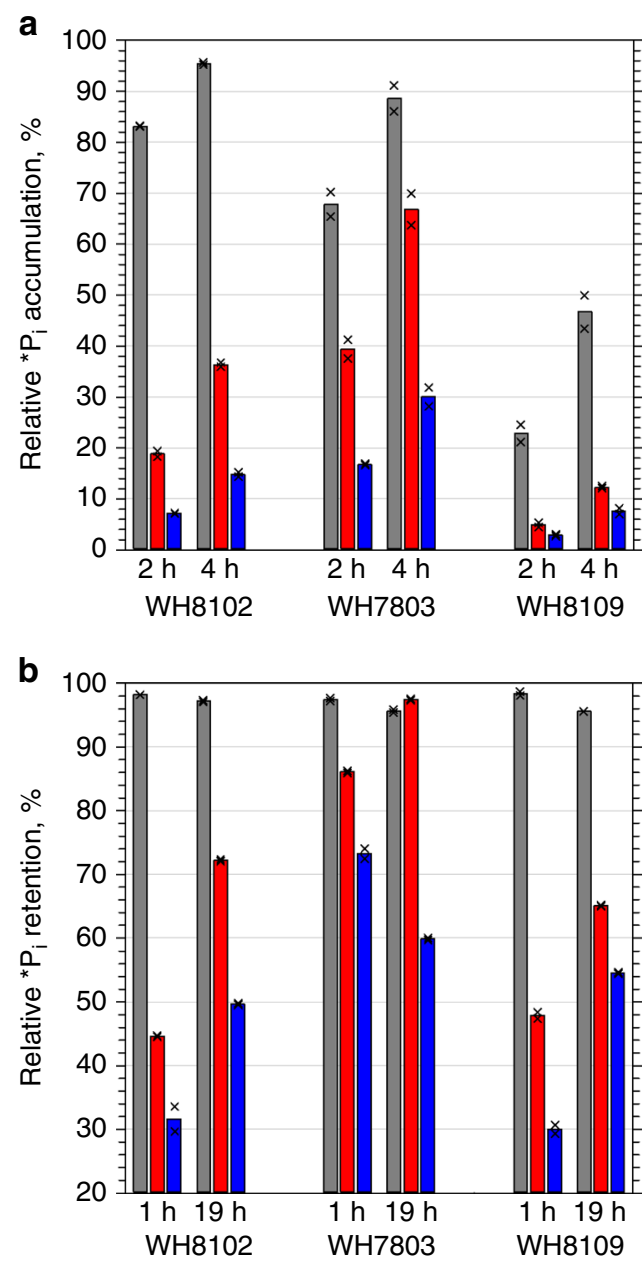

Fig. 4 Accumulation and retention of the accumulated ${ }^{\star} P_{i}$ by

Synechococcus. a The total $P_{i}$ accumulated in live cells (grey bars) compared with the amount of $\mathrm{P}_{\mathrm{i}}$ in PFA-fixed cellular macromolecules (red bars) and TCA-precipitated nucleic acids (blue bars). Cells washed to remove the free $P_{i}$ were re-suspended in ASW- $P_{i}$, supplemented with 100 $\mathrm{Bq} \mathrm{ml}{ }^{-1}$ of $\mathrm{H}_{3}{ }^{32} \mathrm{PO}_{4}$, incubated under standard cultivation conditions and sampled after 2 and $4 \mathrm{~h}$. $\mathbf{b}$ Retention of the total accumulated $P_{i}$ in ${ }^{\star} P_{i}$ prelabelled cells and its internalization into macromolecules and nucleic acids. The pre-labelled cells re-suspended in ASW- $P_{i}$ were incubated under standard cultivation conditions and sampled after 1 and $19 \mathrm{~h}$. The plots show the results of representative experiments. Bars present mean values of technical duplicates indicated as crosses. Horizontal grey lines indicate major ticks of the $\mathrm{Y}$-axis to assist comparing values. Source data are provided as a Source Data file.

(Fig. 7), i.e., ASW diluted 1:10-1:100, phosphate-buffered saline or DW (Supplementary Table 8), which release periplasmic cell contents $^{27,39}$ but do not cause osmotic cell lysis of marine Synechococcus (Fig. 5). Hypotonic washes reproducibly removed an amount of ${ }^{*} \mathrm{P}_{\mathrm{i}}$ less than, or similar to, that removed from the PFA-fixed cellular macromolecules (Figs. 3 and 7). Thus, resistance to a variety of extracellular treatments (Fig. 6) in conjunction with the hypotonic removal of the accumulated $\mathrm{P}_{\mathrm{i}}$ (Figs. 3, 5 and 7) strongly indicates the periplasmic location of the accumulated $\mathrm{P}_{\mathrm{i}}$.

The PMF is essential for $\mathbf{P}_{\mathbf{i}}$ accumulation. The inhibitor CCCP has previously been used to investigate the role of the PMF in various aspects of cyanobacterial physiology ${ }^{26,27}$. Although we used this inhibitor to specifically elucidate the role of the PMF in a
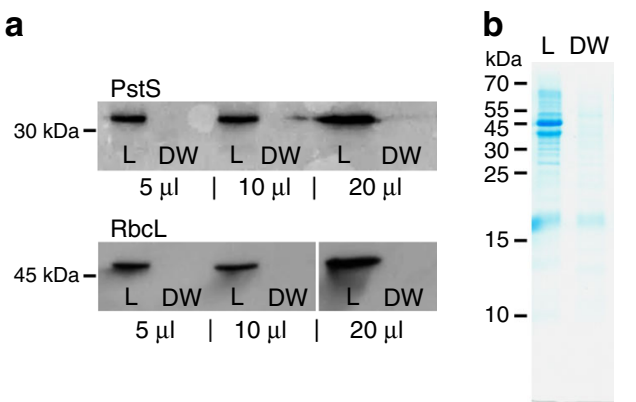

C
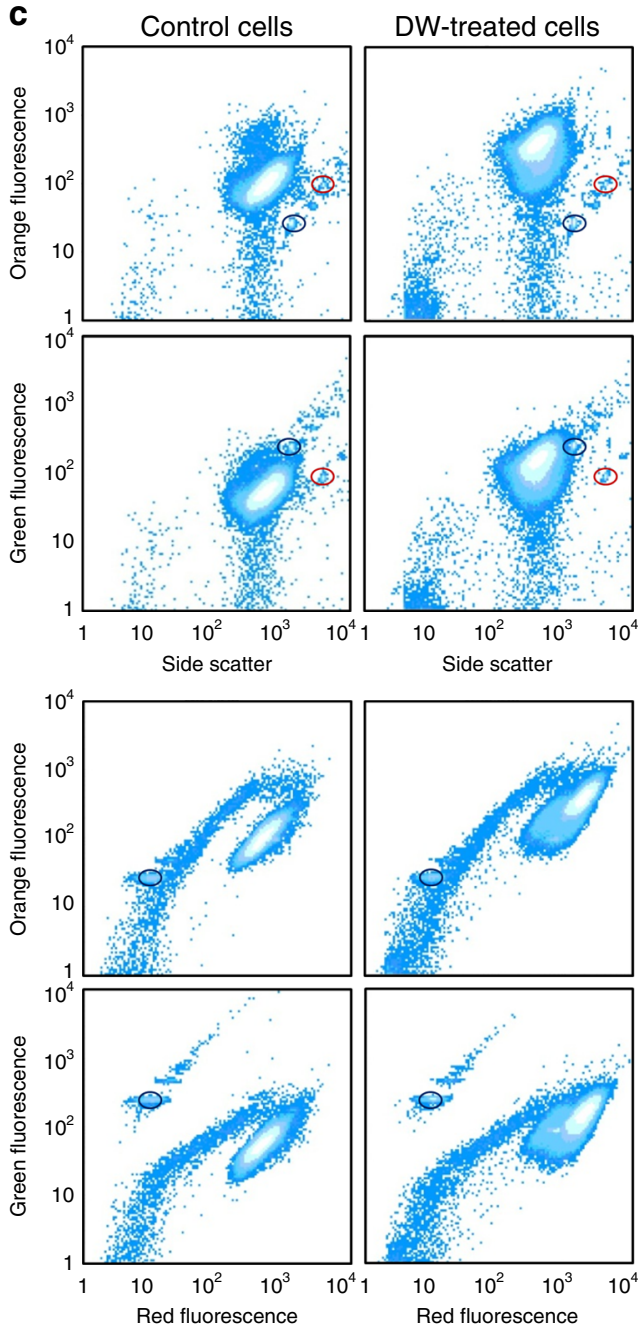

$\mathrm{P}_{\mathrm{i}}$ accumulation by cultured Synechococcus cells, we compared the CCCP effect with the effect of three other metabolic inhibitors (Supplementary Table 7) on $\mathrm{P}_{\mathrm{i}}$ acquisition by oceanic bacterioplankton to safeguard from potential artefacts. A similar time course of $\mathrm{P}_{\mathrm{i}}$ clearance by the control and 3-(3,4-dichloro-phenyl)1,1-dimethylurea (DCMU)-treated bacterioplankton demonstrates that DCMU (which reduces photosynthetic electron flow and proton extrusion) slows down the microbial $\mathrm{P}_{\mathrm{i}}$ clearance rate by $\sim 30 \%$ (Supplementary Fig. 5). This reduction is consistent with the percentage $(\sim 30 \%)$ of cyanobacterial cells within the total bacterioplankton. The other three inhibitors completely terminated $\mathrm{P}_{\mathrm{i}}$ clearance by bacterioplankton, as no time course was observed (Supplementary Fig. 5). The effect of N,N'-dicyclohexyl-carbodiimide (DCCD, an ATPase inhibitor) was delayed three times longer compared with 2,5-dibromo-3-methyl-6- 
Fig. 5 Hypotonic release of the periplasm without lysing Synechococcus sp. WH8102 cells. Western blotting of periplasmic and cell lysate proteins (a, b). Cells were subjected to $1 \mathrm{~min}$ hypotonic shock in deionized water (DW) and pelleted to separate treated cells from supernatant. Proteins present in the DW supernatant were compared with proteins in the lysate $(\mathrm{L})$ of treated cells. a Western blot immunolabeling with antibodies against the periplasmic $\mathrm{P}_{\mathrm{i}}$-binding subunit PstS and the large Rubisco subunit RbcL $(5,10$ or $20 \mu \mathrm{l}$ per lane) reveals the presence of PstS but no signal for RbcL in the DW supernatant. b Coomassie-stained SDS-PAGE (10 $\mu$ per lane) with the size range of proteins in the $L$ and DW samples is shown for reference. $\mathrm{Mw}$, molecular-weight size marker $(\mathrm{kDa})$. The experiment was repeated independently four times with similar results. Comparison of control (left column) and DW-treated cells (right column) using flow cytometric pseudo-colour plots (c) of cellular orange or green autofluorescence vs. red autofluorescence or side scatter. Visualized in BD CellQuest ${ }^{\mathrm{TM}}$ Pro, cellular light scatter and autofluorescence of photosynthetic pigments cluster cells in a single cytometric population separate from a dispersed cluster of other suspended particles and tight clusters of reference beads. Compared with the control cells incubated in ASW medium, the cells incubated in DW for $0.5 \mathrm{~h}$ have higher

autofluorescence but still form a single population, which shows minor deterioration, i.e., cell lysis. Cells were analysed without fixation or staining. The yellow-green (505/515 nm) $0.5 \mu \mathrm{m}$ beads (circled in dark blue) and multifluorescence $1.0 \mu \mathrm{m}$ beads (circled in red) were used as an internal reference. Source data are provided as a Source Data file.

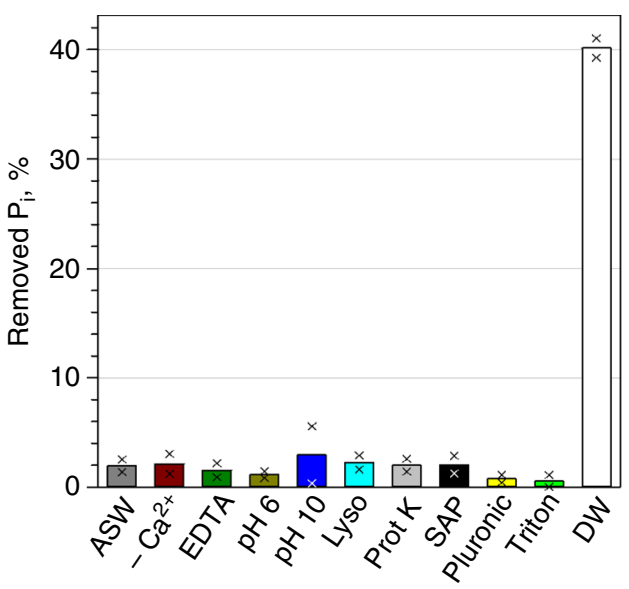

Fig. 6 Retention of the accumulated ${ }^{\star} P_{i}$ by live, pre-labelled

Synechococcus sp. WH8102 cells. Minor removal of $P_{i}$ label was achieved by the following treatments: ASW, cells washed with artificial seawater; $-\mathrm{Ca}^{2+}$, cells washed with ASW without $\mathrm{Ca}^{2+}$; EDTA, cells washed with isotonic $\mathrm{NaCl}$ solution containing EDTA; $\mathrm{pH} 6$ and $\mathrm{pH}$ 10, cells washed with ASW at $\mathrm{pH} 6$ and at $\mathrm{pH} 10$, respectively; Lyso and Prot $\mathrm{K}$, cells incubated with lysozyme and Proteinase $\mathrm{K}$, respectively for $15 \mathrm{~min}$; SAP, cells incubated with shrimp alkaline phosphatase for $30 \mathrm{~min}$; Pluronic and Triton, cells incubated with the surfactants Pluronic F-68 and Triton X-100, respectively, for $15 \mathrm{~min}$. A short wash with deionized water (DW) removed about $40 \%$ of the $\mathrm{P}_{\mathrm{i}}$ label. The plot summarizes the results of the representative experiments. Bars present mean values of technical duplicates indicated as crosses. Horizontal grey lines indicate major ticks of the $\mathrm{Y}$-axis to assist comparisons. For details, refer to Supplementary Tables 5 and 6. Source data are provided as a Source Data file.

isopropylbenzo-quinone (DBMIB) and CCCP, which halted $\mathrm{P}_{\mathrm{i}}$ accumulation after 4 min (Fig. 8a, grey bars).

Likewise, CCCP was a highly effective inhibitor of $\mathrm{P}_{\mathrm{i}}$ accumulation by cultured Synechococcus cells (Fig. 8a). The time delay of 3-5 min common to the three strains was similar to the 4

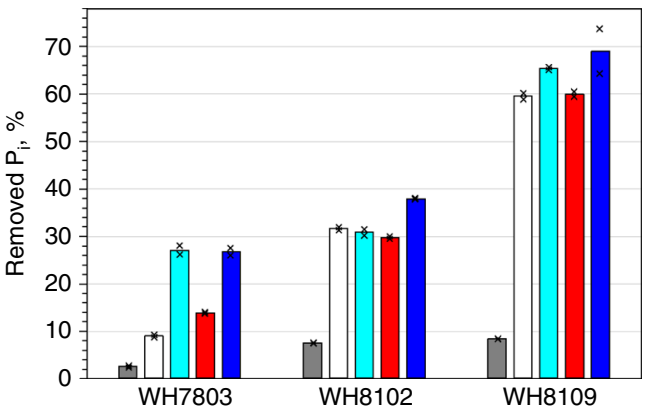

Fig. 7 Osmotic removal of the accumulated $P_{i}$ from the ${ }^{\star} P_{i}$ pre-labelled cells. Comparison of removable ${ }^{*} P_{i}$ from live cells of the three Synechococcus strains incubated for $1 \mathrm{~h}$ and washed with artificial seawater (grey bars), deionized water (white bars) and phosphate-buffered saline (turquoise bars) vs. PFA-fixed cellular macromolecules (red bars) and TCA-precipitated nucleic acids (blue bars). The plot shows the results of a representative experiment. Bars present mean values of technical duplicates indicated as crosses. Horizontal grey lines indicate major ticks of the $\mathrm{Y}$-axis to assist comparisons. Source data are provided as a Source Data file.

min delay of CCCP-treated bacterioplankton. This abrupt halt of $\mathrm{P}_{\mathrm{i}}$ accumulation by CCCP-treated Synechococcus cells indicates that, as in experiments with bacterioplankton (Fig. 8a), membrane depolarization rather than ATP depletion is behind the inhibition, whereas the generic 4 min delay presumably reflects the time required for CCCP molecules to integrate into cellular membranes. As there was $<1 \mathrm{~min}$ to incorporate ${ }^{*} \mathrm{P}_{\mathrm{i}}$ into the PFA-fixed macromolecules and even less time to incorporate it into TCA-fixed nucleic acids (Fig. 1d, e), the bulk of the accumulated $\mathrm{P}_{\mathrm{i}}$ in CCCP-treated cells $(32 \%$ and $11 \%$ of the total $P_{i}$ was in the PFA-fixed macromolecules of oceanic bacteria and isolates, respectively) remained labile (Fig. 8a). This comparison of live and fixed cells worked equally well for bacterioplankton and for cultures (Fig. 8a), confirming that in all bacteria tested $P_{i}$ is first accumulated in the periplasm before being imported into the cytoplasm and assimilated.

The PMF consists of the transmembrane chemical $\mathrm{H}^{+}$gradient $(\Delta \mathrm{pH})$ and the transmembrane electric gradient $(\Delta \Psi)$ that can be sustained by other cations. The protonophore CCCP dissipates both the $\Delta \mathrm{pH}$ and $\Delta \Psi$. To specifically link one of the components to $\mathrm{P}_{\mathrm{i}}$ accumulation in the periplasm, we abolished $\Delta \Psi$ in WH8102 using the three cation-specific ionophores: a $\mathrm{K}^{+}$-specific ionophore (Valinomycin), a monovalent cation-specific (e.g., $\mathrm{Na}^{+}$and $\mathrm{K}^{+}$) ionophore (Monensin) and a divalent metal-specific (e.g., $\mathrm{Mn}^{2+}, \mathrm{Ca}^{2+}$ and $\mathrm{Mg}^{2+}$ ) ionophore (A23187, Supplementary Table 7), which facilitate the electroneutral transport of cations through a membrane down the chemical gradient. Compared with the control, the three ionophores reduced $\mathrm{P}_{\mathrm{i}}$ accumulation into live cells by $0.4 \times, 1.5 \times$ and $2.6 \times$, respectively (Fig. $8 \mathrm{~b}$ ). A significant fraction (20-37\%) of the accumulated $\mathrm{P}_{\mathrm{i}}$ remained in the periplasm. As relative to the protonophore CCCP, the three ionophores had a minor effect on $\mathrm{P}_{\mathrm{i}}$ accumulation by Synechococcus cells (Fig. $8 \mathrm{~b}$ ), we conclude that $\Delta \mathrm{pH}$ rather than $\Delta \Psi$ is crucial for the periplasmic $P_{i}$ accumulation. To validate conclusions about energy-dependent accumulation of $P_{i}$, drawn from the inhibitor-based experiments, we tested whether $P_{i}$ accumulation by SAR11, Prochlorococcus and Synechococcus cells could be energy-stimulated. Conveniently, these bacteria use light energy in their metabolism.

Light stimulation of $\mathbf{P}_{\mathbf{i}}$ accumulation. To test whether light can energize bacterial $P_{i}$ accumulation, we compared $P_{i}$ clearance by oceanic bacterioplankton cells incubated in the light vs. dark 

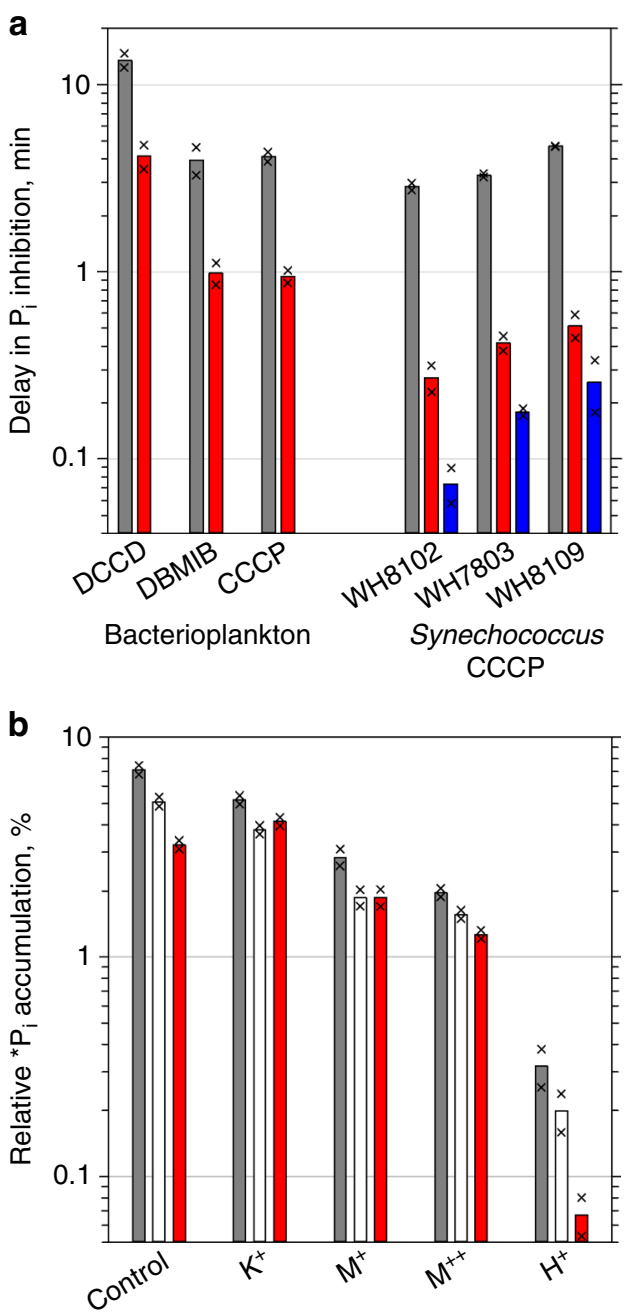

Fig. 8 Inhibition of bacterial $\mathbf{P}_{\mathbf{i}}$ accumulation. a Comparison of the time delay in the inhibition of ${ }^{*} \mathrm{P}_{\mathrm{i}}$ accumulation between bacterioplankton treated with DCCD, DBMIB and CCCP, and Synechococcus strains WH8102, WH7803 and WH8109 treated with CCCP. The time delay is derived from the rate of $P_{i}$ accumulation, measured for uninhibited control cells. b Relative $\mathrm{P}_{\mathrm{i}}$ accumulation in Synechococcus sp. WH8102 cells treated with the $\mathrm{K}^{+}$-specific ionophore Valinomycin $\left(\mathrm{K}^{+}\right)$, the monovalent metalspecific ionophore Monensin $\left(\mathrm{M}^{+}\right)$, the divalent metal-specific ionophore A23187 $\left(\mathrm{M}^{++}\right)$and the protonophore CCCP $\left(\mathrm{H}^{+}\right)$. Plots show the results of representative experiments. Bars present mean values of technical duplicates indicated as crosses. Horizontal grey lines indicate major ticks of the logarithmic $\mathrm{Y}$-axis to assist comparing values for the following treatments: $P_{i}$ accumulation into live cells washed with seawater (grey bars), into PFA-fixed cellular macromolecules (red bars) and into TCA-fixed cellular nucleic acids (blue bars) (a) or into the cytoplasm (white bars) of cells washed with deionized water $(\mathbf{b})$. Source data are provided as a Source Data file.

(Fig. 9). Indeed, light enhanced $P_{i}$ accumulation by all cells studied (Supplementary Table 9). Compared with spectacular $(\leq 10$ times) but sporadic light stimulation of $\mathrm{P}_{\mathrm{i}}$ clearance by Prochlorococcus cells (and to a lesser extent by Synechococcus cells), light stimulation of $\mathrm{P}_{\mathrm{i}}$ clearance by SAR11 cells was more uniform, averaging $40 \%$ (Fig. 9). Counter-intuitively, light stimulation was distinctly more pronounced at lower rates of $\mathrm{P}_{\mathrm{i}}$ clearance in moderately $\mathrm{P}_{\mathrm{i}}$-depleted waters bordering the North Atlantic subtropical gyre but absent at the maximal rates of $\mathrm{P}_{\mathrm{i}}$ clearance in the $\mathrm{P}_{\mathrm{i}}$-depleted gyre (Fig. 9 and Supplementary Table 2).

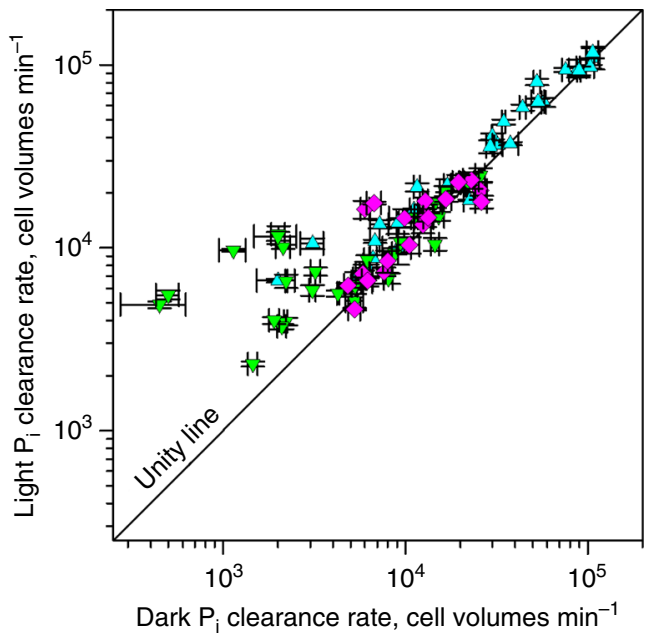

Fig. 9 Comparison of $P_{i}$ clearance rates of oceanic cells in the light versus dark. Comparison of $P_{i}$ clearance rates in cell volume equivalents of oceanic SAR11 (turquoise triangles, $n=28$ ), Prochlorococcus (green triangles, $n=$ 32) and Synechococcus (pink diamonds, $n=19$ ) at ambient $P_{i}$ concentrations. Equivalents of cell volumes cleared of $P_{i}$ per minute were used to negate the bacterial size differences. Symbols present mean values of four sorting replicates of the paired light vs. dark experiments; error bars indicate corresponding SD. Source data are provided as a Source Data file. Values above the unity line indicate light stimulation.

\section{Discussion}

Accumulation of $\mathrm{P}_{\mathrm{i}}$ in the periplasm starts with $\mathrm{P}_{\mathrm{i}}$ diffusion from seawater. The theoretical maximal rate of $P_{i}$ diffusion into the periplasm of a Gram-negative cell depends on a $P_{i}$ diffusion coefficient and the permeable surface area ${ }^{10,11}$. The $P_{i}$ diffusion coefficeint is a seawater trait affecting all cells equally. Cells could, however, control their $\mathrm{P}_{\mathrm{i}}$-permeable surface area by varying the number of OM porins. Prochlorococcus and Synechococcus strains respond to $\mathrm{P}_{\mathrm{i}}$ limitation by the increased expression of $\mathrm{P}_{\mathrm{i}}$-specific porin genes and the increased abundance of porin proteins ${ }^{14,40,41}$. However, the number of these porins in the OM cannot increase indefinitely. Indeed, the maximal $\mathrm{P}_{\mathrm{i}}$ clearance rates of oceanic cyanobacterial and SAR11 cells (Fig. 2 a) converge towards $\sim 30 \times$ below the theoretical maximum. The apparent upper limit to the number of $\mathrm{P}_{\mathrm{i}}$-specific OM porins is probably a result of the competition for space between porins selective for different small solutes, acquisition of which is essential for a living cell.

In contrast to other solutes, $\mathrm{P}_{\mathrm{i}}$ somehow accumulates in the periplasm. Synechococcus cells rapidly accumulate labile $\mathrm{P}_{\mathrm{i}}$, which is then steadily internalized and assimilated into macromolecules (Figs. 3 and 4). The semi-labile nature of the accumulated $\mathrm{P}_{\mathrm{i}}$ (hypotonic removal, Figs. 1c, 3 and 5-7) in conjunction with its resistance to a variety of extracellular treatments (Fig. 6) points to its periplasmic location. Diffusion-driven $P_{i}$ acquisition ${ }^{11}$ can deplete environmental $\mathrm{P}_{\mathrm{i}}$ concentrations at a constant clearance rate down to $10^{-12} \mathrm{moll}^{-1}$ (Fig. 2a). This is feasible only if the periplasmic $\mathrm{P}_{\mathrm{i}}$ concentration of Synechococcus cells is $<10^{-12} \mathrm{moll}^{-1}$. Even if we assume that the affinity of the Synechococcus PstS subunit for $\mathrm{P}_{\mathrm{i}}$ is sufficient to bind $\mathrm{P}_{\mathrm{i}}$ at $<10^{-12} \mathrm{moll}^{-1}$ concentrations (five orders of magnitude below the determined affinity ${ }^{20}$ ) then every $\mathrm{P}_{\mathrm{i}}$ molecule that enters and stays in the Synechococcus periplasm needs to be instantly bound by a PstS subunit (Fig. 1a $\dagger$ ). Sequestration of $6.7 \times 10^{6}$ molecules (Fig. 2b) of labile $\mathrm{P}_{\mathrm{i}}$ in the periplasm would require an equal number of PstS subunits. The volume of a PstS subunit of $3.5 \times 4 \times 7 \mathrm{~nm}$ dimensions ${ }^{42}$ is $\sim 5.1 \times 10^{-23} 1$, whereas the periplasmic volume of Synechococcus is 
$\sim 2 \times 10^{-17} 1$. This is sufficient to accommodate merely $4 \times 10^{5} \mathrm{PstS}$ subunits, or $17 \times$ less than the number required. However, even if $4 \times 10^{5}$ PstS subunits cram into the periplasm, there would be no room left for other known periplasmic constituents: substrate binding subunits of at least some of 41 other ABC-type transporters in $\mathrm{WH} 8102^{43}$, periplasmic enzymes, e.g., alkaline phosphatase ${ }^{6,44}$ and aminopeptidase ${ }^{45}$, and peptidoglycan gel matrix-the major structural component of periplasm ${ }^{46}$. As Prochlorococcus cells that have a smaller periplasm ${ }^{47}$ can have as many ABC-type transporters and periplasmic enzymes as $\mathrm{WH} 8102^{43}$ but accumulate more $P_{i}$ in their buffer $\left(1.2 \times 10^{7}\right.$ molecules $\left.^{22}\right)$, it makes it even less probable that all periplasmic $\mathrm{P}_{\mathrm{i}}$ is bound by PstS subunits. Finally, up to $20 \times$ more $\mathrm{P}_{\mathrm{i}}$ (e.g., at the $3 \mathrm{~h}$ time point in Fig. $3 \mathrm{~b}$, d, yellow) remains labile in living Synechococcus cells than is incorporated into bacterial macromolecules (which should include PFA-cross-linked PstS subunits, Fig. 1d). As the PstS-mediated $\mathrm{P}_{\mathrm{i}}$ uptake model (Fig. 1a $\dagger$ ) cannot explain the results of our experiments, an alternative explanation is required.

The evident capacity of Synechococcus to import the accumulated $\mathrm{P}_{\mathrm{i}}$ into the cytoplasm (Figs. 3 and $4 \mathrm{~b}$ ) is inconsistent with passive sorption of $\mathrm{P}_{\mathrm{i}}$ to the outer cell surface ${ }^{48,49}$, because passively adsorbed $\mathrm{P}_{\mathrm{i}}$ cannot effectively diffuse into the periplasm (Fig. 1a $\dagger$ ). Passive sorption of $P_{i}$ by marine bacteria is furthermore questionable, because metabolically inactive but structurally intact bacterioplankton cells (e.g., CCCP-, DBMIB-, DCCDincapacitated cells) should retain their capacity to adsorb $\mathrm{P}_{\mathrm{i}}$ passively, but instead, they do not adsorb ${ }^{*} \mathrm{P}_{\mathrm{i}}$ present in seawater for hours (Supplementary Fig. 5). In contrast, the rapid cessation or slowing down of $\mathrm{P}_{\mathrm{i}}$ accumulation caused by the specific inhibitors (Fig. 8) and light stimulation of $P_{i}$ accumulation (Fig. 9) indicates that $\mathrm{P}_{\mathrm{i}}$ accumulation in the periplasm is a metabolically active process.

Light could enhance $P_{i}$ accumulation by SAR11 cells through a proteorhodopsin-generated $\mathrm{PMF}^{50}$. Cyanobacteria could use photosynthetically generated PMF for the same purpose. The former energy generator consistently increased $\mathrm{P}_{\mathrm{i}}$ accumulation by $40 \%$, whereas the latter energy generator showed a higher $(\leq 10 \times)$ potential to boost $\mathrm{P}_{\mathrm{i}}$ accumulation by Prochlorococcus cells (Fig. 9). Although such considerable light stimulation is notable, the most unexpected result of the light vs. dark experiments was the lack of light stimulation at the higher rates of $P_{i}$ accumulation (Fig. 9) in the $P_{i}$-depleted waters of the North Atlantic subtropical gyre ${ }^{22}$. Apparently, under severe $\mathrm{P}_{\mathrm{i}}$ depletion, bacteria do not rely on light as the primary energy source for $P_{i}$ acquisition but use their internal energy sources. $\mathrm{P}_{\mathrm{i}}$ accumulation seems so important for bacteria that their maximal $\mathrm{P}_{\mathrm{i}}$ clearance rates $(\sim 30 \times$ below the theoretical maximal rate of nutrient acquisition by diffusion) are probably constrained by the limited OM surface for incorporating $\mathrm{P}_{\mathrm{i}}$-specific porins rather than by the availability of cellular energy.

It seems inexplicable that bacteria can accumulate millions of $\mathrm{P}_{\mathrm{i}}$ molecules (Figs. 2b and 3b, d, and Supplementary Fig. 2b) in their periplasm, while maintaining diffusion even at exceedingly low environmental concentrations. The high percentage of ${ }^{*} \mathrm{P}_{\mathrm{i}}$ present in the periplasm (Figs. 4-7) and the gradual assimilation of accumulated $\mathrm{P}_{\mathrm{i}}$ (Figs. 3-4) indicates that the rate of periplasmic $\mathrm{P}_{\mathrm{i}}$ accumulation by far exceeds the rate of $\mathrm{P}_{\mathrm{i}}$ import. The parallel import of ${ }^{33} \mathrm{P}_{\mathrm{i}}$ pulse and ${ }^{32} \mathrm{P}_{\mathrm{i}}$ chase (Fig. 3) means that the spatial distribution of $\mathrm{P}_{\mathrm{i}}$ in the periplasm is not ordered. Bacteria do not synthesize polyphosphates in the periplasm but somehow make $P_{i}$ molecules semi-labile: accessible for PstS subunits but prevented from diffusing back into seawater. On the one hand, periplasmic $P_{i}$ needs to remain in ionic form rather than phosphorylate organic molecules, because PstS subunits specifically bind $\mathrm{HPO}_{4}{ }^{2-}$ and $\mathrm{H}_{2} \mathrm{PO}_{4}^{-}$ions ${ }^{42}$. On the other hand, $\mathrm{P}_{\mathrm{i}}$ cannot be maintained as free ions because a few free $\mathrm{P}_{\mathrm{i}}$ ions would make the periplasmic concentration of $\mathrm{P}_{\mathrm{i}}$ above the environmental concentration and hence reverse diffusion. The nearly instantaneous termination of $\mathrm{P}_{\mathrm{i}}$ accumulation (Fig. $8 \mathrm{a}$ ) by the inhibitors CCCP and DBMIB (which dissipate the PMF and thereby halt ATP generation), compared with the delayed reduction of $\mathrm{P}_{\mathrm{i}}$ accumulation by DCCD (which primarily blocks ATP generation and thus destroys ATP-sustained membrane potential), strongly indicates that $\mathrm{P}_{\mathrm{i}}$ accumulation is linked to cellular energetics through the PFM rather than being directly driven by ATP through PstSCAB-type transporters (Fig. 1a $\dagger$ ). The mutually exclusive conditions (listed above) of PMF-dependent $\mathrm{P}_{\mathrm{i}}$ accumulation in the periplasm cannot be explained by PstS-mediated $P_{i}$ import (Fig. 1a $\dagger$ ). Therefore, an alternative mechanism is needed.

An alternative mechanism of PMF-dependent $\mathrm{P}_{\mathrm{i}}$ accumulation in the periplasm is a conjecture, because we know little about the organization and functioning of the periplasm ${ }^{46}$ in a living bacterial cell. A cell maintains the PMF by extruding protons $\left(\mathrm{H}^{+}\right.$ ions) across the plasma membrane against the electrochemical gradient using the energy of respiration and photosynthesis ${ }^{50-52}$. Accumulation of $\mathrm{H}^{+}$in the periplasm would make it acidic relative to both the cytoplasm $\left(\mathrm{pH} \sim 7.2^{53}\right)$ and seawater $(\mathrm{pH}$ $8.0-8.3^{54}$ ) (Fig. 1ał). However, it is unlikely that many free $\mathrm{H}^{+}$ ions would accumulate in the periplasm of marine bacteria, because their $\mathrm{OM}$ is permeable to the smallest $\mathrm{H}^{+}$ions. Hence, $\mathrm{H}^{+}$ions should diffuse out into the environment to be neutralized by $>100 \times$ excess of $\mathrm{OH}^{-}$ions in alkaline ( $\mathrm{pH} 8.0-8.3$ ) seawater ${ }^{54}$, thereby dissipating the membrane potential. To prevent the dissipation of the $\mathrm{H}^{+}$-based gradient, $\mathrm{H}^{+} / \mathrm{Na}^{+}$antiporters may exchange at least some of the periplasmic $\mathrm{H}^{+}$ions for $\mathrm{Na}^{+}$ions ${ }^{55}$. This substitution could preserve the electrical gradient and support ATP production through $\mathrm{H}^{+}$-ATP synthases, which can transport $\mathrm{Na}^{+56}$. Genes for both the $\mathrm{H}^{+} / \mathrm{Na}^{+}$ antiporter and the $\mathrm{Na}^{+}$-driven ATP synthase are present in genomes of Prochlorococcus ${ }^{56}$ and Synechococcus isolates (e.g., NP_87599956, WP_010315318, WP_025922676, WP_002805629 and WP_062436653).

The electric potential between the acidic positively charged periplasm and the alkaline seawater would facilitate diffusion, or more precisely mass transfer, of anions with higher negative charge more strongly than anions with lower negative charge. Thereby, mass transfer through anion-selective porins ${ }^{13}$ of $\mathrm{HPO}_{4}{ }^{2-}$ and $\mathrm{PO}_{4}{ }^{3-}$ anions (which comprise $29 \%$ and $0.01 \%$ of the total $\mathrm{P}_{\mathrm{i}}$ in seawater at $\mathrm{pH} 8.0$, respectively ${ }^{57,58}$ ) would be particularly favourable. Stronger cationic association of the main seawater anions (e.g., $\mathrm{Cl}^{-}, \mathrm{HSO}_{4}^{-}, \mathrm{HCO}_{3}^{-}$and $\mathrm{NO}_{3}^{-}$) would also favour mass transfer of free $\mathrm{P}_{\mathrm{i}}$ anions. Once in the $\mathrm{H}^{+}$ enriched periplasm, the $\mathrm{HPO}_{4}{ }^{2-}$ and $\mathrm{PO}_{4}{ }^{3-}$ anions would associate with one or two $\mathrm{H}^{+}$and metal cations to reach $\mathrm{pH}$ dependent speciation equilibrium ${ }^{57,58}$. Kinetic stability of neutral $\mathrm{P}_{\mathrm{i}}$ molecules would explain why disruption of the membrane potential only has a minor immediate effect on the $\mathrm{P}_{\mathrm{i}}$ already accumulated in the periplasm (Supplementary Fig. 4).

Neutralization of cations with $\mathrm{P}_{\mathrm{i}}$ anions would reduce the PMF, but that could be restored via continuous extrusion of $\mathrm{H}^{+}$and cations across the plasma membrane to maintain mass transfer of $\mathrm{P}_{i}$ anions through porins as long as free $\mathrm{P}_{i}$ anions can mass transfer from the environment (Fig. 1a ). Mass transfer would stop when equilibrium is reached, i.e., all $\mathrm{P}_{\mathrm{i}}$ anions remaining in seawater are too strongly associated with environmental cations and molecules of water. The strength of their association depends on the total ionic composition of environmental solutions ${ }^{58}$; in seawater, the association of $\mathrm{P}_{\mathrm{i}}$ anions is apparently weak, because we observed bacterial accumulation of $\mathrm{P}_{\mathrm{i}}$ anions to continue down to environmental concentrations $<10^{-12} \mathrm{moll}^{-1}$ (Fig. 2) and even $<10^{-15} \mathrm{moll}^{-1}$ (Supplementary Table 4 ). 
Although the periplasm becomes saturated with $\mathrm{P}_{\mathrm{i}}$ in $1 \mathrm{~h}$ (e.g., $4 \times 10^{6} \mathrm{P}_{\mathrm{i}}$ molecules in $2.1 \times 10^{-17} \mathrm{l}$ periplasm equals $0.3 \mathrm{moll}^{-1}$, Fig. 3b, d), a cell somehow averts precipitation of the $P_{i}$ salts in the periplasm. To prevent formation of insoluble $\mathrm{P}_{\mathrm{i}}$ salts, a cell would need to minimize concentrations of divalent cations (e.g., $\mathrm{Ca}^{2+}$ and $\mathrm{Mg}^{2+}$, which associate with $\mathrm{P}_{\mathrm{i}}$ to form salts with low solubility) in the periplasm, while balancing the concentrations of monovalent cations (e.g., $\mathrm{Na}^{+}$and $\mathrm{K}^{+}$) and $\mathrm{P}_{\mathrm{i}}$ anions to form neutral soluble ion pairs in a way analogous to the common phosphate buffer. Although cation-associated, the $\mathrm{H}_{2} \mathrm{PO}_{4}{ }^{-}$and $\mathrm{HPO}_{4}{ }^{2-}$ ions remain accessible to PstS-mediated (the PstS subunits have specific affinity to these two anion forms ${ }^{42}$ ) import, because they remain soluble (Fig. 1a $¥$ ). Formation of neutral ion pairs would maintain mass transfer of $\mathrm{HPO}_{4}{ }^{2-}$ and $\mathrm{PO}_{4}{ }^{3-}$ into the periplasm, and prevent $\mathrm{H}^{+}$from escaping into seawater. To simplify the explanations we give below, we suggest to term this periplasmic $\mathrm{H}^{+}$-driven phosphate-cation associationphosphatation.

Maintaining maximal rates of $\mathrm{P}_{\mathrm{i}}$ acquisition irrespective of the availability of light energy (Fig. 9) suggests that periplasmic phosphatation is functionally important for marine bacteria as different as cyanobacteria and SAR11 alphaproteobacteria. We propose the following three physiological functions of periplasmic phosphatation: (i) The periplasmic association of $P_{i}$ with chemiosmotic cations accumulates not only $\mathrm{P}_{\mathrm{i}}$, but also cations. Accumulation of the latter could be viewed as energy conservation, because $\mathrm{H}^{+} / \mathrm{Na}^{+}$import through the plasma membrane can generate ATP59,60. (ii) The high concentration of $P_{i}$ accumulated in the periplasm could also ensure that the PstS transport system is always saturated with $\mathrm{P}_{\mathrm{i}}$ and operates near its maximal rate. (iii) Periplasmic phosphatation could have an osmotic function. The concentration of $\mathrm{P}_{\mathrm{i}}$ in the periplasm can increase by $0.3 \mathrm{moll}^{-1}$ in just $1 \mathrm{~h}$ (e.g., $4 \times 10^{6} \mathrm{P}_{\mathrm{i}}$ molecules in $2.1 \times 10^{-17} 1$ periplasm, Fig. $3 \mathrm{~b}, \mathrm{~d}$ ) and reach $>0.5 \mathrm{moll}^{-1}$ within $3 \mathrm{~h}$. Accumulation of an additional $0.5 \mathrm{moll}^{-1}$ of $\mathrm{P}_{\mathrm{i}}$ salt would increase periplasmic osmolarity by $\sim 0.5 \mathrm{osmol}^{-1}$. Considering that there are other osmotically active molecules in the periplasm, and that the $P_{i}$ salt concentration could raise further the periplasmic osmolarity, this would easily exceed the osmolarity of seawater, i.e., $\sim 1$ osmol $^{-157}$. To equilibrate, the resultant osmotic differential water molecules would enter the periplasm increasing its volume and the OM turgor (Fig. 1a $\ddagger$ ), explaining how the OM could work as a load-bearing element ${ }^{61}$. Therefore, we predict that periplasmic phosphatation is essential for bacterial osmotic regulation-a hypothesis worth testing experimentally.

There is little doubt that the cationic attraction of $\mathrm{P}_{\mathrm{i}}$ anions predates life. It was proposed that back in the earliest Archean, positively charged clay particles in oceanic cold alkaline seeps could be viewed as primordial membranes of protocells ${ }^{62}$. Their positive charge would similarly attract $P_{i}$ anions from seawater and this initial enrichment of clay particles with $P_{i}$ might have been inherited by the first living forms, who gradually engaged $P_{i}$ in cellular energetics and later genetics. Thus, periplasmic phosphatation is inherently essential for bacterial cells, because it could conserve energy as well as store and attract the vital $\mathrm{P}_{\mathrm{i}}$.

\section{Methods}

Environmental sampling. Data were collected on five oceanographic cruises (Supplementary Table 2) on board the Royal Research Ships James Clark Ross (JCR), James Cook (JC), Discovery III (D) and Discovery IV (DY), and the Research Vessel Maria S. Merian (MSM) in the North Atlantic during Atlantic Meridional Transect cruises AMT17-D299, AMT20-JC053, AMT22-JC079 and AMT27DY084 in September-October 2005, 2010, 2012 and 2017, respectively, and during the MSM03 cruise in September-October 2006. At predawn, midday and occasional evening stations seawater samples were collected from $20 \mathrm{~m}$ (a representative depth from the surface mixed layer unaffected by the ship's movement and contamination) using a $20 \times 201$ Niskin bottle rosette (Miami, FL, USA) mounted on the stainless steel frame of a conductivity-temperature-depth profiler. Samples were decanted into $10 \mathrm{l}$ polyethylene carboys. Experiments commenced within 1-2 $\mathrm{h}$ after sample collection. The concentrations of bioavailable $\mathrm{P}_{\mathrm{i}}$ were determined using isotope dilution, concentration series bioassays ${ }^{7,22}$ with carrier-free ${ }^{32} \mathrm{P}$-labelled or ${ }^{33} \mathrm{P}$-labelled orthophosphoric acid (Hartmann Analytic GmbH, Braunschweig, Germany). Bioassay experiments were performed in polypropylene screw cap, $2 \mathrm{ml}$ micro-centrifuge tubes (Starlab, Milton Keynes, UK). Flow-sorting experiments and experiments with inhibitors were performed in Pyrex glass bottles (Fisher Scientific, Loughborough, UK). To minimize artificial contamination (e.g., $\mathrm{P}_{\mathrm{i}}$, other nutrients, heavy metals), all plastic-ware, glassware and silicone tubing were soaked in $10 \% \mathrm{HCl}$ and repeatedly rinsed with DW and sampled seawater.

Synechococcus strains and growth conditions. We chose Synechococcus sp. WH8102, because its $\mathrm{P}_{\mathrm{i}}$ acquisition and utilization strategies are known ${ }^{1,41}$. This strain belongs to clade III that is generally considered to be adapted to low-nutrient conditions ${ }^{63,64}$ and abundant in $\mathrm{P}_{\mathrm{i}}$-depleted Atlantic waters ${ }^{65}$. Strain Synechococcus sp. WH8109 is a member of clade II, a clade that dominates tropical and subtropical regions of the world's ocean ${ }^{66,67}$, tolerates intermediate nutrient-depleted conditions ${ }^{64,67}$ and lives in nutrient-richer upwelling waters ${ }^{65}$. It was reasonable to expect that these strains accumulate $P_{i}$ extracellularly, because they grow better under $\mathrm{P}_{\mathrm{i}}$-depleted rather than under $\mathrm{P}_{\mathrm{i}}$-replete conditions ${ }^{30}$. To elucidate whether the $P_{i}$ accumulation was specific to cyanobacterial ecotypes that had evolved to cope with $\mathrm{P}_{\mathrm{i}}$ deprivation, we also included an opportunistic strain Synechococcus sp. WH7803 (clade V) that reaches a maximal growth rate when supplemented with $\geq 10^{-6} \mathrm{moll}^{-1} \mathrm{P}_{\mathrm{i}}^{49}$.

Cultures of Synechococcus sp. WH8102 and Synechococcus sp. WH7803 were axenic. An axenic culture of Synechococcus sp. WH8109 strain was established by flow sorting. Live bacterial cells in a mixed culture were stained with $0.1 \mu \mathrm{g} \mathrm{ml}^{-1}$ Hoescht 33342 (final concentration) and Synechococcus sp. WH8109 cells were flow cytometrically differentiated from other bacteria by their specific autofluorescence. Using a custom-built MoFlo XDP instrument ${ }^{68}$, WH8109 cells were flow-sorted in batches of 10-200 cells directly into sterile tubes with ASW medium. Tubes were placed into an illuminated growth chamber and incubated until growth became evident by colour.

Axenic cultures of Synechococcus sp. strains WH8102, WH8109 and WH7803 were cultivated in an ASW medium ${ }^{70}$ prepared using American Chemical Society grade reagents and supplemented with $8 \times 10^{-5} \mathrm{~mol} \mathrm{l}^{-1} \mathrm{~K}_{2} \mathrm{HPO}_{4}$. Semi-continuous cultures were maintained at $23^{\circ} \mathrm{C}$ with gentle agitation at 100 r.p.m. on an orbital shaker at a light intensity of $\sim 20 \mu \mathrm{mol}$ photons $\mathrm{m}^{-2} \mathrm{~s}^{-1}$. Axenic cultures were monitored regularly for contamination by plating $\sim 10^{6}$ cells on ASW agar plates containing $0.5 \mathrm{~g} \mathrm{l}^{-1}$ yeast extract and were contaminant free. To maintain trace $\mathrm{P}$ conditions, glassware used for $\mathrm{P}_{\mathrm{i}}$-free cultivation and experiments was soaked in $10 \% \mathrm{HCl}$ and thoroughly rinsed with DW.

Cell enumeration and flow sorting. Cultured Synechococcus cells were counted live, unstained, to assess their cell integrity during laboratory experiments (e.g., see Fig. 5 c). Oceanic samples were fixed with PFA ( $1 \% \mathrm{w} / \mathrm{v}$ final concentration), stained with SYBR Green I DNA dye 69 at $20^{\circ} \mathrm{C}$ in the dark for $1 \mathrm{~h}$ and flow cytometrically counted and sorted ${ }^{22,70}$ (Supplementary Fig. 1). Bacterioplankton cells flow-sorted during the D299 and JC053 cruises were taxonomically identified using fluorescence in situ hybridization ${ }^{7,9}$. High nucleic acid-containing bacteria with virtually undetectable chlorophyll autofluorescence ${ }^{71}$ were identified as Prochlorococcus. Low nucleic acid-containing bacteria were identified as SAR11 alphaproteobacteria. Oceanic Synechococcus were identified flow cytometrically based on their specific orange autofluorescence ${ }^{7}$.

Western blot analyses. Cells from an exponentially growing Synechococcus WH8102 culture $\left(\mathrm{OD}_{750}=0.25\right)$ were starved for $\mathrm{P}_{\mathrm{i}}$ to induce PstS synthesis. After $60 \mathrm{~h}$ incubation, $800 \mathrm{ml}$ cells were pelleted by centrifugation, washed twice with 20 $\mathrm{ml} \mathrm{ASW}$ and subjected to $1 \mathrm{~min}$ hypotonic shock in $6 \mathrm{ml} \mathrm{DW}$. Following centrifugation, supernatant $(6 \mathrm{ml})$ was collected. The remaining cell pellet was sus pended in $6 \mathrm{ml}$ cold DW, supplemented with Protease Inhibitor Cocktail II (Abcam) and the cells were disrupted by two passes through a high-pressure Cell Disruptor (Constant Systems Ltd, Northants, UK). Intact cells were removed from hypotonic DW supernatant and disrupted cells by short centrifugation $(5000 \times g$, $10 \mathrm{~min}, 4^{\circ} \mathrm{C}$ ). Large membrane debris of disrupted cells were removed using highspeed centrifugation $\left(20,000 \times g, 60 \mathrm{~min}, 4^{\circ} \mathrm{C}\right)$ and the remaining cell lysate $(6 \mathrm{ml})$ was collected. Volumes $(5,10$ or $20 \mu \mathrm{l})$ of DW supernatant and cell lysate were denatured with $1: 3(\mathrm{v} / \mathrm{v})$ sample buffer at $90^{\circ} \mathrm{C}$ for $5 \mathrm{~min}$ and separated by SDSpolyacrylamide gel electrophoresis using $14 \%$ acrylamide. A reference gel was stained with Coomassie blue. Western blot immunolabelling used antibodies against the periplasmic phosphate-binding subunit $\operatorname{PstS}^{72}$ (1:10,000 dilution) and the large Rubisco subunit RbcL (1 : 10,000; AS03 037, Agrisera). For western blotting, proteins were transferred to the polvinylidene difluoride (PVDF) membrane and analysed using standard protocols, following the use of a horseradish peroxidase (HRP)-conjugated goat anti-rabbit IgG HRP-linked secondary antibody $\left(1: 5000 ; \# 7074\right.$, Cell Signaling Technology $\left.{ }^{\circledast}\right)$. 
Pulse-chase experiments. Exponentially growing Synechococcus sp. WH8102 cells $\left(0.3-3 \times 10^{7}\right.$ cells $\left.\mathrm{ml}^{-1}\right)$ were collected on a $0.2 \mu \mathrm{m}$ pore size Nuclepore tracketched filter membrane (Whatman International, Ltd, Maidstone, UK) mounted in a filter holder (Swinnex, Millipore, Ireland) and washed with $40 \mathrm{ml} \mathrm{P}_{\mathrm{i}}$-free ASW

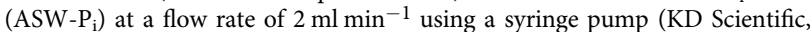
Holliston, MA, USA). The washed cells were pulsed with $10^{-8} \mathrm{moll}^{-1} \mathrm{P}_{\mathrm{i}}$ traced with ${ }^{33} \mathrm{P}_{\mathrm{i}}\left(\mathrm{H}_{3}{ }^{33} \mathrm{PO}_{4}\right.$, specific activity $\sim 111 \mathrm{TBq} \mathrm{mmol}^{-1}$; Hartmann Analytic $\mathrm{GmbH}$, Braunschweig, Germany) for $2 \mathrm{~h}$. The pulse was chased with $100 \times \mathrm{P}_{\mathrm{i}}$ concentration $\left(10^{-6} \mathrm{~mol} \mathrm{l}^{-1}\right)$ traced with carrier-free ${ }^{32} \mathrm{P}_{\mathrm{i}}\left(\mathrm{H}_{3}{ }^{32} \mathrm{PO}_{4}\right.$, specific activity $\sim 222 \mathrm{TBq} \mathrm{mmol}^{-1}$; Hartmann Analytic $\mathrm{GmbH}$, Braunschweig, Germany) and incubated for up to $23 \mathrm{~h}$. Retention of ${ }^{33} \mathrm{P}_{\mathrm{i}}$ and ${ }^{32} \mathrm{P}_{\mathrm{i}}$ was determined for live and PFA-fixed cells (Fig. 3). Dissolved tracer was washed from live cells with ASW$\mathrm{P}_{\mathrm{i}}$ using a $0.2 \mu \mathrm{m}$ pore size PVDF membrane spin column (Proteus Mini, Generon, Maidenhead, UK): $0.5 \mathrm{ml}$ cells were placed in a column, spun down at $5000 \times \mathrm{g}$ for $1 \mathrm{~min}$ and washed thrice with $0.1 \mathrm{ml}$ of ASW- $\mathrm{P}_{\mathrm{i}}$. The radioactivity was determined separately for the cells retained in the spin column insert and for the effluent in the collection tube. To fix cells, $0.5-1.5 \mathrm{ml}$ cells were fixed with $1 \%$ PFA, incubated at ambient temperature for $1 \mathrm{~h}$ and filtered on $0.2 \mu \mathrm{m}$ pore size polycarbonate filters. Filters were rinsed twice with $4 \mathrm{ml} \mathrm{DW}$, placed in $20 \mathrm{ml}$ scintillation vials (Meridian, Epsom, UK), mixed with $10 \mathrm{ml}$ scintillation cocktail (Goldstar, Meridian) and radioassayed using a low-activity liquid scintillation analyser (Tri-Carb 3180 TR/SL, PerkinElmer, Beaconsfield, UK) with QuantaSmart ${ }^{\mathrm{mt}}$ software. To assess their reproducibility, the pulse-chase experiments were repeated thrice. The results of two experiments are presented in Fig. 3.

Extracellular $\mathbf{P}_{\mathbf{i}}$ labelling of Synechococcus cells. Cells washed of free $\mathrm{P}_{\mathrm{i}}$ were resuspended in $20 \mathrm{ml}$ ASW- $\mathrm{P}_{\mathrm{i}}$, supplemented with $80-160 \mathrm{~Bq} \mathrm{ml}^{-1}$ of $\mathrm{H}_{3}{ }^{33} \mathrm{PO}_{4}$ or $\mathrm{H}_{3}{ }^{32} \mathrm{PO}_{4}$ and incubated in a glass bottle under standard cultivation conditions for $1-3 \mathrm{~h}$. The labelled cells were collected on $0.2 \mu \mathrm{m}$ pore size Nuclepore filters and effluent was sampled to determine the efficiency of ${ }^{*} \mathrm{P}_{\mathrm{i}}$ clearance (Supplementary Table 4). Extracellularly ${ }^{*} P_{\text {i }}$ pre-labelled Synechococcus cells were washed free of residual ${ }^{*} \mathrm{P}_{\mathrm{i}}$ with $20 \mathrm{ml}$ ASW- $\mathrm{P}_{\mathrm{i}}$ and re-suspended in solutions appropriate for further experiments.

Retention of the accumulated $\mathbf{P}_{\mathrm{i}} \cdot{ }^{*} \mathrm{P}_{\mathrm{i}}$ pre-labelled Synechococcus cells were treated with enzymes (Supplementary Table 6) or re-suspended in a range of solutions (Supplementary Tables 5 and 8) using either a $0.2 \mu \mathrm{m}$ pore size PVDF membrane spin column or a $0.2 \mu \mathrm{m}$ pore size Nuclepore membrane filter fitted in a $13 \mathrm{~mm}$ diameter Swinnex filter holder. For treatments in spin columns, $0.3-0.5 \mathrm{ml}$ treated cells were incubated in a column, spun down at $5000 \times g$ for $1 \mathrm{~min}$ and washed thrice with $0.1 \mathrm{ml}$ of an appropriate washing solution. The radioactivity was determined separately for the cells retained in the spin column insert and for the effluent in the collection tube. Alternatively, cells were collected on a Nuclepore membrane, washed with $10 \mathrm{ml}$ of a treatment solution at a rate of $0.5-1 \mathrm{ml} \mathrm{min}^{-1}$ and the radioactivity determined for the filter membrane only. The activity of the protease Proteinase K in ASW was confirmed using the PDQ protease assay (Athena Environmental Sciences, Inc., Baltimore, MD, USA). To assess their reproducibility, all experiments were repeated independently at least thrice.

Inhibition experiments. Inhibitors were dissolved in dimethyl sulfoxide (DMSO) and added to samples to a final concentration of $0.05-1 \times 10^{-4} \mathrm{moll}^{-1}$ (Supplementary Table 7) simultaneously with the ${ }^{33} \mathrm{P}_{\mathrm{i}}$ or ${ }^{32} \mathrm{P}_{\mathrm{i}}$ tracer. To provide a control, samples were supplemented with the appropriate amount of DMSO. Accumulation of ${ }^{*} \mathrm{P}_{\mathrm{i}}$ in DMSO-amended samples and control samples without DMSO addition was similar (Shapiro-Wilk normality test passes $P=0.932$, paired $t$-test $t=-0.155$ with 8 degrees of freedom, two-tailed $P$-value 0.881 ). Samples were incubated in the light under ambient conditions and sub-samples were withdrawn periodically to determine the total microbial $\mathrm{P}_{\mathrm{i}}$ accumulation. To assess their reproducibility, all experiments were repeated independently at least thrice.

Microbeam synchrotron X-ray fluorescence analysis. These measurements were performed at the Diamond Light Source, the UK National Synchrotron Facility. Beamline I18 (Microfocus Spectroscopy) was used to measure the amount of P in cells of Prochlorococcus cyanobacteria (range $1-5 \times 10^{5}$ cells) and Synechococcus sp. strain WH8102 (0.1-1 $\times 10^{6}$ cells) (Supplementary Table 3 ). Cells were flow-sorted onto $0.2 \mu \mathrm{m}$ pore size polycarbonate filters (P free) using the custom-built MoFlo XDP instrument ${ }^{68}$. The filters with dried sorted cells were mounted on a custom-made sample holder and the cell-containing filter areas $(\sim 1000 \times 2000 \mu \mathrm{m})$ were probed with a beam spot of $30 \times 30 \mu \mathrm{m}^{2}$ in a helium atmosphere (Supplementary Fig. 3a-c). An approximation of the number of photons on the sample was derived by measuring a thin-film reference material with known mass deposition of a number of metals. This calculated photon flux applied to the cells and accounting for differences in sample matrix, density and volume, leads to an estimated P mass per pixel for the cells. From these values, the total number of $\mathrm{P}$ atoms was derived for each cell preparation by integrating signal from all P containing pixels using PyMCA X-ray Fluorescence Toolkit (http://pymca.sourceforge.net) and ImageJ 1.50i (https://imagej. nih.gov/ij/). Using the cultured Synechococcus cells as calibrants, sensitivity $\left(\geq 2 \times 10^{4}\right.$ cells) and linear range $\left(\leq 7.5 \times 10^{5}\right)$ of the method were determined.
The determined P content was $4.14 \pm 1.06 \times 10^{6} \mathrm{P}$ atoms per cell for oceanic Prochlorococcus equivalent to 1.3-3.1 genomes (accessions: ASM1148v1, ASM1246v1, ASM1264v1, ASM1564v1, ASM1566v1, ASM1858v1, ASM75985v1, ASM792v1 and ASM1146v1). The extracellularly accumulated $P_{i}$ of cells was removed during sorting by the sheath fluid of low osmotic concentration $\left(\sim 0.03\right.$ osmoll $\left.^{-1}\right)$, which strips the extracellularly bound $\mathrm{P}_{\mathrm{i}}$ (Figs. 1, 3, and 5-7). Therefore, only intracellular phosphorus was measured for the sorted cells. In comparison, the P content calculated for an exponentially growing extracellular $\mathrm{P}_{\mathrm{i}}$-free Synechococcus sp. WH8102 cell was $1.9 \pm 0.16 \times 10^{7}$ $\mathrm{P}$ atoms, which is $\sim 4$ times the genomic $\mathrm{P}$ content (ASM19597v1).

Microscopy. Bacterioplankton cells were imaged and their dimensions measured $^{68}$ (Supplementary Fig. 3d-f and Supplementary Table 1). Cells of Synechococcus sp. WH8102 were imaged using a LSM780 Confocal Laser Scanning Microscope (Carl Zeiss, Jena, Germany), using $488 \mathrm{~nm}$ (Ar) and $594 \mathrm{~nm}(\mathrm{HeNe})$ laser lines.

Statistics and reproducibility. Each experiment was repeated independently at least three times and often more than ten times.

Reporting summary. Further information on research design is available in the Nature Research Reporting Summary linked to this article.

\section{Data availability}

The auxiliary data collected on research cruises are archived indefinitely at the British Oceanographic Data Centre (BODC) and are available at www.bodc.ac.uk. The $\mu$-SXRF data are available from Open Science Framework at http://osf.io/6RH2V. All other data supporting the findings of this study are available within the paper and its Supplementary Information files. The source data underlying Figs. $2-4$ and 6-9, and Supplementary Figs. 2, 4 and 5 are provided as a Source Data file.

Received: 12 February 2019; Accepted: 24 April 2020; Published online: 26 May 2020

\section{References}

1. Moore, L. R., Ostrowski, M., Scanlan, D. J., Feren, K. \& Sweetsir, T. Ecotypic variation in phosphorus acquisition mechanisms within marine picocyanobacteria. Aquat. Microb. Ecol. 39, 257-269 (2005).

2. Sohm, J. A. \& Capone, D. G. Phosphorus dynamics of the tropical and subtropical north Atlantic: Trichodesmium spp. versus bulk plankton. Mar. Ecol. Prog. Ser. 317, 21-28 (2006).

3. Dyhrman, S. T. \& Haley, S. T. Phosphorus scavenging in the unicellular marine diazotroph Crocosphaera watsonii. Appl. Environ. Microbiol. 72, 1452-1458 (2006).

4. Van Mooy, B. A., Rocap, G., Fredricks, H. F., Evans, C. T. \& Devol, A. H. Sulfolipids dramatically decrease phosphorus demand by picocyanobacteria in oligotrophic marine environments. Proc. Natl Acad. Sci. USA 103, 8607-8612 (2006).

5. Mather, R. L. et al. Phosphorus cycling in the North and South Atlantic Ocean subtropical gyres. Nat. Geosci. 1, 439 (2008).

6. Sebastian, M. \& Ammerman, J. W. The alkaline phosphatase PhoX is more widely distributed in marine bacteria than the classical PhoA. ISME J. 3, 563 (2009).

7. Zubkov, M. V. et al. Microbial control of phosphate in the nutrient-depleted North Atlantic subtropical gyre. Environ. Microbiol. 9, 2079-2089 (2007).

8. Michelou, V. K., Lomas, M. W. \& Kirchman, D. L. Phosphate and adenosine$5^{\prime}$-triphosphate uptake by cyanobacteria and heterotrophic bacteria in the Sargasso Sea. Limnol. Oceanogr. 56, 323-332 (2011).

9. Gomez-Pereira, P. R. et al. Comparable light stimulation of organic nutrient uptake by SAR11 and Prochlorococcus in the North Atlantic subtropical gyre. ISME J. 7, 603-614 (2013).

10. Koch, A. L. in Advances in Microbial Ecology (ed. Marshall, K.C.) 37-70 (Springer, USA, 1990)

11. Jumars, P. A. et al. Physical constraints on marine osmotrophy in an optimal foraging context. Aquat. Microb. Ecol. 7, 121-159 (1993).

12. Nikaido, H. \& Vaara, M. Molecular basis of bacterial outer membrane permeability. Microbiol. Rev. 49, 1-32 (1985).

13. Pongprayoon, P., Beckstein, O., Wee, C. L. \& Sansom, M. S. P. Simulations of anion transport through OprP reveal the molecular basis for high affinity and selectivity for phosphate. Proc. Natl Acad. Sci. USA 106, 21614-21618 (2009).

14. Fuszard, M. A., Wright, P. C. \& Biggs, C. A. Cellular acclimation strategies of a minimal picocyanobacterium to phosphate stress. FEMS Microbiol. Lett. 306, $127-134(2010)$. 
15. Rosenberg, H., Gerdes, R. \& Chegwidden, K. Two systems for the uptake of phosphate in Escherichia coli. J. Bacteriol. 131, 505-511 (1977).

16. Willsky, G. R. \& Malamy, M. H. Characterization of two genetically separable inorganic phosphate transport systems in Escherichia coli. J. Bacteriol. 144, 356-365 (1980).

17. Lebens, M., Lundquist, P., Söderlund, L., Todorovic, M. \& Carlin, N. I. The nptA gene of Vibrio cholerae encodes a functional sodium-dependent phosphate cotransporter homologous to the type II cotransporters of eukaryotes. J. Bacteriol. 184, 4466-4474 (2002).

18. Sowell, S. M. et al. Transport functions dominate the SAR11 metaproteome at low-nutrient extremes in the Sargasso Sea. ISME J. 3, 93 (2008).

19. Scanlan, D. J. et al. Ecological genomics of marine picocyanobacteria. Microbiol. Mol. Biol. Rev. 73, 249-299 (2009).

20. Neznansky, A., Blus-Kadosh, I., Yerushalmi, G., Banin, E. \& Opatowsky, Y. The Pseudomonas aeruginosa phosphate transport protein PstS plays a phosphate-independent role in biofilm formation. FASEB J. 28, 5223-5233 (2014).

21. McCarren, J. et al. Inactivation of $s w m A$ results in the loss of an outer cell layer in a swimming Synechococcus strain. J. Bacteriol. 187, 224-230 (2005).

22. Zubkov, M. V., Martin, A. P., Hartmann, M., Grob, C. \& Scanlan, D. J. Dominant oceanic bacteria secure phosphate using a large extracellular buffer. Nat. Commun. 6, 7878 (2015).

23. Temperton, B., Gilbert, J. A., Quinn, J. P. \& McGrath, J. W. Novel analysis of oceanic surface water metagenomes suggests importance of polyphosphate metabolism in oligotrophic environments. PLoS ONE 6, el6499 (2011)

24. Li, P. -N. et al. Nutrient transport suggests an evolutionary basis for charged archaeal surface layer proteins. ISME J. 12, 2389-2402 (2018).

25. Li, W. K. W. \& Dickie, P. M. Metabolic inhibition of size-fractionated marine plankton radiolabeled with amino acids, glucose, bicarbonate, and phosphate in the light and dark. Microb. Ecol. 11, 11-24 (1985).

26. Spiller, H., Stallings, W. Jr, Tu, C. \& Gunasekaran, M. Dependence of $\mathrm{H}^{+}$ exchange and oxygen evolution on $\mathrm{K}^{+}$in the marine cyanobacterium Synechococcus sp. strain UTEX 2380. Can. J. Microbiol. 40, 257-265 (1994).

27. Ikeya, T., Ohki, K., Takahashi, M. \& Fujita, Y. Study on phosphate uptake of the marine cyanophyte Synechococcus sp. NIBB 1071 in relation to oligotrophic environments in the open ocean. Mar. Biol. 129, 195-202 (1997).

28. Strahl, H. \& Hamoen, L. W. Membrane potential is important for bacterial cell division. Proc. Natl Acad. Sci. USA 107, 12281-12286 (2010).

29. Kendall, A. I. Bacterial metabolism. Physiol. Rev. 3, 438-455 (1923).

30. Mazard, S., Wilson, W. H. \& Scanlan, D. J. Dissecting the physiological response to phosphorus stress in marine Synechococcus isolates (Cyanophyceae). J. Phycol. 48, 94-105 (2012).

31. Zubkov, M. V. Faster growth of the major prokaryotic versus eukaryotic $\mathrm{CO}_{2}$ fixers in the oligotrophic ocean. Nat. Commun. 5, 3776 (2014)

32. Mary, I. et al. Light enhanced amino acid uptake by dominant bacterioplankton groups in surface waters of the Atlantic Ocean. FEMS Microbiol. Ecol. 63, 36-45 (2008).

33. Zubkov, M. V. \& Sleigh, M. A. Ingestion and assimilation by marine protists fed on bacteria labeled with radioactive thymidine and leucine estimated without separating predator and prey. Microb. Ecol. 30, 157-170 (1995).

34. Frece, J. et al. Importance of S-layer proteins in probiotic activity of Lactobacillus acidophilus M92. J. Appl. Microbiol. 98, 285-292 (2004).

35. Parsot, C., Ménard, R., Gounon, P. \& Sansonetti, P. J. Enhanced secretion through the Shigella flexneri Mxi-Spa translocon leads to assembly of extracellular proteins into macromolecular structures. Mol. Microbiol. 16, 291-300 (2006).

36. Brahamsha, B. An abundant cell-surface polypeptide is required for swimming by the nonflagellated marine cyanobacterium Synechococcus. Proc. Natl Acad. Sci. USA 93, 6504-6509 (1996).

37. Martin, N. L. \& Beveridge, T. J. Gentamicin interaction with Pseudomonas aeruginosa cell envelope. Antimicrob. Agents Chemother. 29, 1079-1087 (1986).

38. Masschalck, B. \& Michiels, C. W. Antimicrobial properties of lysozyme in relation to foodborne vegetative bacteria. Crit. Rev. Microbiol. 29, 191-214 (2003).

39. Heppel, L. A. Selective release of enzymes from bacteria. Science 156, 1451-1455 (1967).

40. Martiny, A. C., Coleman, M. L. \& Chisholm, S. W. Phosphate acquisition genes in Prochlorococcus ecotypes: evidence for genome-wide adaptation. Proc. Natl Acad. Sci. USA 103, 12552-12557 (2006).

41. Tetu, S. G. et al. Microarray analysis of phosphate regulation in the marine cyanobacterium Synechococcus sp. WH8102. ISME J. 3, 835-849 (2009).

42. Luecke, H. \& Quiocho, F. A. High specificity of a phosphate transport protein determined by hydrogen bonds. Nature 347, 402-406 (1990).

43. Scanlan, D. J. \& West, N. J. Molecular ecology of the marine cyanobacterial genera Prochlorococcus and Synechococcus. FEMS Microbiol. Ecol. 40, 1-12 (2002).
44. Palenik, B. et al. The genome of a motile marine Synechococcus. Nature $\mathbf{4 2 4}$, 1037-1042 (2003)

45. Martinez, J. \& Azam, F. Aminopeptidase activity in marine Chroococcoid cyanobacteria. Appl. Environ. Microbiol. 59, 3701-3707 (1993).

46. Hobot, J. A., Carlemalm, E., Villiger, W. \& Kellenberger, E. Periplasmic gel: new concept resulting from the reinvestigation of bacterial cell envelope ultrastructure by new methods. J. Bacteriol. 160, 143-152 (1984).

47. Ting, C. S., Hsieh, C., Sundararaman, S., Mannella, C. \& Marko, M. Cryoelectron tomography reveals the comparative three-dimensional architecture of Prochlorococcus, a globally important marine cyanobacterium. J. Bacteriol. 189, 4485-4493 (2007).

48. Sanudo-Wilhelmy, S. A. et al. The impact of surface-adsorbed phosphorus on phytoplankton Redfield stoichiometry. Nature 432, 897-901 (2004).

49. Fu, F.-X., Zhang, Y., Feng, Y. \& Hutchins, D. A. Phosphate and ATP uptake and growth kinetics in axenic cultures of the cyanobacterium Synechococcus CCMP 1334. Eur. J. Phycol. 41, 15-28 (2006).

50. Walter, J. M., Greenfield, D., Bustamante, C. \& Liphardt, J. Light-powering Escherichia coli with proteorhodopsin. Proc. Natl Acad. Sci. USA 104, 2408-2412 (2007).

51. Scholes, P., Mitchell, P. \& Moyle, J. The polarity of proton translocation in some photosynthetic microorganisms. Eur. J. Biochem. 8, 450-454 (1969).

52. Nitschmann, W. H. \& Peschek, G. A. Oxidative phosphorylation and energy buffering in cyanobacteria. J. Bacteriol. 168, 1205-1211 (1986).

53. Belkin, S. \& Packer, L. Determination of $\mathrm{pH}$ gradients in intact cyanobacteria by electron spin resonance spectroscopy. Methods Enzymol. 167, 670-677 (1988).

54. Marion, G. M. et al. pH of seawater. Mar. Chem. 126, 89-96 (2011).

55. Padan, E. \& Schuldiner, S. Molecular physiology of $\mathrm{Na}^{+} / \mathrm{H}^{+}$antiporters, key transporters in circulation of $\mathrm{Na}^{+}$and $\mathrm{H}^{+}$in cells. Biochim. Biophys. Acta Bioenerg. 1185, 129-151 (1994).

56. Dufresne, A. et al. Genome sequence of the cyanobacterium Prochlorococcus marinus SS120, a nearly minimal oxyphototrophic genome. Proc. Natl Acad. Sci. USA 100, 10020-10025 (2003).

57. Atlas, E., Culberson, C. \& Pytkowicz, R. M. Phosphate association with $\mathrm{Na}^{+}$, $\mathrm{Ca}^{2+}$ and $\mathrm{Mg}^{2+}$ in seawater. Mar. Chem. 4, 243-254 (1976).

58. Dickson, A. G. \& Riley, J. P. The estimation of acid dissociation constants in sea-water media from potentiometric titrations with strong base. II. The dissociation of phosphoric acid. Mar. Chem. 7, 101-109 (1979).

59. Skulachev, V. P. The sodium cycle: a novel type of bacterial energetics. $J$. Bioenerg. Biomembr. 21, 635-647 (1989).

60. Müller, V. \& Grüber, G. ATP synthases: structure, function and evolution of unique energy converters. Cell Mol. Life Sci. 60, 474-494 (2003).

61. Rojas, E. R. et al. The outer membrane is an essential load-bearing element in Gram-negative bacteria. Nature 559, 617 (2018).

62. Martin, W. \& Russell, M. J. On the origins of cells: a hypothesis for the evolutionary transitions from abiotic geochemistry to chemoautotrophic prokaryotes, and from prokaryotes to nucleated cells. Philos. Trans. R. Soc. B 358, 59-85 (2003)

63. Zwirglmaier, K. et al. Basin-scale distribution patterns of picocyanobacterial lineages in the Atlantic Ocean. Environ. Microbiol. 9, 1278-1290 (2007).

64. Post A. F. in Harmful Cyanobacteria (eds Huisman, J., Matthijs, H. C. P. \& Visser, P. M.) Ch. 5 (Springer, 2005).

65. Mazard, S., Ostrowski, M., Partensky, F. \& Scanlan, D. J. Multi-locus sequence analysis, taxonomic resolution and biogeography of marine Synechococcus. Environ. Microbiol. 14, 372-386 (2012).

66. Farrant, G. K. et al. Delineating ecologically significant taxonomic units from global patterns of marine picocyanobacteria. Proc. Natl Acad. Sci. USA 113, E3365-E3374 (2016).

67. Sohm, J. A. et al. Co-occurring Synechococcus ecotypes occupy four major oceanic regimes defined by temperature, macronutrients and iron. ISME J. 10, 333-345 (2016).

68. Kamennaya, N. A., Kennaway, G., Fuchs, B. M. \& Zubkov, M. V. "Pomacytosis"-Semi-extracellular phagocytosis of cyanobacteria by the smallest marine algae. PLoS Biol. 16, e2003502 (2018).

69. Zubkov, M. V., Burkill, P. H. \& Topping, J. N. Flow cytometric enumeration of DNA-stained oceanic planktonic protists. J. Plankton Res. 29, 79-86 (2007).

70. Marie, D., Partensky, F., Jacquet, S. \& Vaulot, D. Enumeration and cell cycle analysis of natural populations of marine picoplankton by flow cytometry using the nucleic acid stain SYBR Green I. Appl. Environ. Microbiol. 63, 186-193 (1997)

71. Hartmann, M. et al. Efficient $\mathrm{CO}_{2}$ fixation by surface Prochlorococcus in the Atlantic Ocean. ISME J. 8, 2280 (2014).

72. Scanlan, D. J., Mann, N. H. \& Carr, N. G. The response of the picoplanktonic marine cyanobacterium Synechococcus species WH7803 to phosphate starvation involves a protein homologous to the periplasmic phosphatebinding protein of Escherichia coli. Mol. Microbiol. 10, 181-191 (1993). 


\section{Acknowledgements}

We thank the captains, officers, crew and chief scientists of the research cruises JCR091, MSM03, JC053, JC079 and DY084. We are grateful to M. A. Sleigh and D. Green for their supportive criticism of earlier versions of the manuscript, to J. Wulf, I. Mary, C. Grob and M. Hartmann for help with experiments at sea, and to H. Zer for help with the biochemical analysis. This study was supported by the UK Natural Environment Research Council through Research grants NE/M014363/1 and NE/J02273X/1. We acknowledge the Diamond Light Source for beam time under proposal NT15802-1.

\section{Author contributions}

M.V.Z. and N.A.K. conceived the project, designed and performed the experiments, analysed and interpreted the data and co-wrote the manuscript. K.G. designed and performed $\mu$-SXRF phosphorus measurements and analysed data. D.J.S. contributed expert advice. M.V.Z. and D.J.S. provided funding. All authors critically edited the manuscript.

\section{Competing interests}

The authors declare no competing interests.

\section{Additional information}

Supplementary information is available for this paper at https://doi.org/10.1038/s41467020-16428-w.

Correspondence and requests for materials should be addressed to M.V.Z.
Peer review information Nature Communications thanks Adam Martiny, and the other, anonymous, reviewer(s) for their contribution to the peer review of this work.

Reprints and permission information is available at http://www.nature.com/reprints

Publisher's note Springer Nature remains neutral with regard to jurisdictional claims in published maps and institutional affiliations.

\section{(c) (i)}

Open Access This article is licensed under a Creative Commons Attribution 4.0 International License, which permits use, sharing, adaptation, distribution and reproduction in any medium or format, as long as you give appropriate credit to the original author(s) and the source, provide a link to the Creative Commons license, and indicate if changes were made. The images or other third party material in this article are included in the article's Creative Commons license, unless indicated otherwise in a credit line to the material. If material is not included in the article's Creative Commons license and your intended use is not permitted by statutory regulation or exceeds the permitted use, you will need to obtain permission directly from the copyright holder. To view a copy of this license, visit http://creativecommons.org/ licenses/by/4.0/.

(c) The Author(s) 2020 